What is known about the secondary traumatisation of staff working with offending populations? A Review of the Literature

\author{
Laura Frost ${ }^{1}$ and Helen Scott ${ }^{1}$
}

${ }^{1}$ School of Life Sciences and Education, Staffordshire University. Room 206, Science Centre, 32 Leek Road, Stoke-on-Trent, ST4 2RU
Author contact details
Laura Frost: laura.frost@mpft.nhs.uk
Dr Helen Scott: h.scott@staffs.ac.uk 


\section{What is known about the secondary traumatisation of staff working with offending populations? A Review of the Literature}

\section{$\underline{\text { Abstract }}$}

Being secondarily exposed to trauma through working with traumatised clients can be challenging for professionals, sometimes leading to them developing secondary traumatic stress (STS) and/or vicarious trauma (VT). Experiences of VT and STS have primarily been researched in relation to staff working with trauma survivors. Perpetrators of offences have also often experienced traumatic events in their lives and may be traumatised by the offence they have committed. This review aims to summarise what is known about the prevalence and development of VT and STS in populations of any staff working with adult offenders. Relevant literature was identified by searching appropriate databases, and hand searching was conducted to identify any grey literature or omitted articles. Eleven studies were identified, critically reviewed and synthesised. All the studies found VT or STS to be present within their samples. Staff were largely categorised as being at low to moderate risk for STS. No studies attempted to clarify the level of VT within their sample. Factors associated with VT and STS are discussed. This literature base was challenging to synthesize due to a lack of conceptual clarity and methodological issues within the included studies. The findings suggest that staff working with offending populations do experience VT and STS and that support could be improved to assist in mitigating the effects.

Key Words: Vicarious trauma, secondary traumatic stress, compassion fatigue, offenders, staff 
Introduction

Human service professionals caring for people who have experienced traumatic events such as physical or sexual abuse, combat or disasters have frequently been found to experience negative consequences associated with being secondarily exposed to trauma during their work (Bride \& Figley, 2009; Creamer \& Liddle, 2005; Salston \& Figley, 2003). Groups of professionals found to be affected by being secondarily exposed to trauma include social workers (Bride, 2007), therapists (Canfield, 2005), substance abuse clinicians (Huggard et al., 2017), law enforcement investigators (Perez et al., 2010) and nurses (Beck, 2011).

Vicarious trauma (VT) and secondary traumatic stress (STS) are similar yet distinct concepts, devised to describe a collection of difficulties that staff can experience following being secondarily exposed to trauma. Another commonly used term for STS is compassion fatigue. For the purpose of this review, both compassion fatigue and STS will be referred to as STS because this is the term most frequently used throughout the literature.

\section{Vicarious Trauma (VT) and Secondary Traumatic Stress (STS)}

Vicarious trauma refers to the reactions which can be experienced by professionals empathically engaging with traumatised clients (McCann \& Pearlman, 1990), such as grief, anxiety or sadness. VT is a cognitive change process whereby beliefs and thoughts about the world are negatively impacted. This may present as staff feeling less safe, trusting others less, struggling with intimacy or feeling powerless both in their personal and professional lives. Characteristically, VT has a pervasive impact upon all areas of life and a cumulative effect, whereby each exposure to client trauma gradually increases the impact. Effects are longstanding and potentially permanent (Moulden \& Firestone, 2007). 
Post-traumatic stress disorder (PTSD) typically occurs following direct exposure to trauma, such as being assaulted or being injured in an accident (American Psychiatric Association, 2013). The original definition of PTSD, however, has been expanded to acknowledge that trauma reactions can occur in response to indirect exposure to traumatic events, including hearing about trauma's which loved ones have experienced and professionals being indirectly exposed to trauma whilst at work (American Psychiatric Association, 2013). STS is considered to occur following a professional being traumatised by hearing about a traumatic event which has happened to a client (Figley, 2002). These definitions of PTSD and STS are very similar, making it difficult to differentiate between them. This will be discussed further within the limitations section of the review. The signs of PTSD and STS are also reported to be similar, although, STS is considered less severe (Lerias \& Byrne, 2003). STS indicators include intrusive thoughts, images or dreams about the described trauma (Romey, 2005). Cognitive changes and mood changes are also common, for example, feeling isolated, holding exaggerated feelings of blame/anger regarding the traumatic event or struggling with low mood (Figley, 2002). People with STS may have difficulty separating work from their personal life and practise unhealthy self-soothing behaviours, such as increased alcohol use (Gentry et al., 2002). In comparison to staff not experiencing STS, staff with STS are considered more likely to take sick leave, make poor professional judgements and make mistakes, leading to client dissatisfaction (Pfifferling \& Gilley, 2000; Rudolph et al., 1997). Experiences of STS can begin suddenly, sometimes immediately following an isolated interaction with a client during which a traumatic event is described (Jenkins \& Baird, 2002). 
Enduring covert changes to the belief system is focussed upon by VT, whilst STS emphasises observable reactions which can be more easily resolved with intervention (Jenkins \& Baird, 2002). There are reported definitional overlaps between the constructs of VT and STS (Thomas \& Wilson, 2004), leading to the terms being used interchangeably. Tests of discriminant validity have suggested VT is experienced differently and is distinct from STS (Watts \& Robertson, 2015), primarily due to the extensive cognitive changes said to occur with VT (Baird \& Kracen, 2006). The key commonalities lie in their development through second-hand exposure to and internalisation of traumatic material experienced during work with clients (Jenkins \& Baird, 2002). Further, STS and VT share components of PTSD symptoms and generalised distress (Jenkins \& Baird, 2002). It is understood that professionals working with trauma survivors can experience both VT and STS concurrently (Pearlman \& MacIan, 1995).

Not all clinicians working with clients who have experienced trauma develop VT or STS. This has led researchers to investigate factors which may make some professionals more vulnerable. A meta-analysis by Hensel et al. (2015) investigated STS in those working therapeutically with traumatised clients identified risk factors such as: holding a caseload with high numbers of traumatised clients (and few non-traumatised clients), frequent contact with traumatised clients, and a personal history of trauma. Protective factors included greater social support and work support. Demographic factors were found to have little influence (Hensel et al., 2015). For VT, a research synthesis demonstrated having a personal trauma history to be a risk factor, whereas supervision and a perceived ability to cope were protective factors (Baird \& Kracen, 2006). 
Both VT and STS have been found to be associated with higher burnout, namely, experiencing reduced levels of personal accomplishment, greater emotional exhaustion and feeling detached from themselves and clients (Cieslak et al., 2014; Craig \& Sprang, 2010; Maslach et al., 1966; Shoji et al., 2015). This can lead to higher rates of staff turnover, diminished capacity to enjoy life, reduced productivity and difficulties maintaining personal and professional relationships (Showalter, 2010). Due to significant negative impacts, interventions have been utilised with staff with the aim of reducing VT and STS (Bercier \& Maynard, 2015). A systematic review of interventions for STS demonstrated mixed or no effects on STS, although the results may have been impacted by the low to moderate quality design of included studies (Cocker \& Joss, 2016). Interventions demonstrating reductions in STS included elements of education and/or building resilience.

\section{Staff Working with Offender Populations}

Traditionally, VT and STS have been considered in relation to working with survivors of traumatic events. There is increasing recognition that staff working with offenders may additionally be at risk of VT and STS (Way et al., 2004). It has consistently been found that offenders have frequently previously experienced traumatic events (Berg et al., 2012; Jennings et al., 2012; Pizarro et al., 2011), commonly referred to as the 'victim-offender overlap' (Lauritsen \& Laub, 2007). The literature is lacking regarding details of previous traumatic experiences which link to offending (Jennings et al., 2012). One study demonstrated significant associations between experiencing sexual abuse, emotional abuse, neglect, and future sexual offending (Jennings et al., 2014). Those who have perpetrated offences that are traumatic to others can be traumatised by their own actions and experience 'offence related PTSD' (Friel et al., 2008; MacNair, 2002). Prevalence rates for offence related PTSD have been found to range from 15\% (Collins \& Bailey, 1990) to 32\% (Steiner 
et al., 1997) within violent offenders, and between 33\% (Gray et al., 2003) to 40\% (Crisford et al., 2008) for offenders with mental health difficulties. Offenders may not be personally distressed by their crimes, but staff can still experience strong emotional reactions from listening to details of crimes (Moulden \& Firestone, 2007). This suggests that staff who work with people who have offended, may be exposed to both clients own personal histories of trauma and offence related trauma, potentially leaving staff vulnerable to STS and VT. There is the additional risk within forensic services of staff being exposed to violence directly (being assaulted) or indirectly (witnessing or hearing about assaults) whilst at work (Broderick et al., 2015; Isenhardt \& Hostettler, 2020), indirect exposure could contribute to the development of STS and VT.

Preliminary research suggests there are no differences in levels of VT experienced between those working with offenders and those working with survivors of crime (Way et al., 2004). A review of VT in therapists working with sexual offenders was conducted in 2007 by Moulden and Firestone. The findings suggested that this population is susceptible to VT; however, estimates of the prevalence rates varied. The levels of VT were increased within therapists working in secure settings in comparison to those working in community settings. Coping strategies were identified as playing an important role in the development of VT, but some of the findings were conflicting. Several studies concluded that positive coping strategies (e.g. self-care, exercise, support) were protective against VT, but other studies found both positive and negative coping strategies (e.g. pornography, alcohol) to be associated with increased levels of VT (Moulden \& Firestone, 2007). 


\section{Rationale of the Literature Review}

This literature review focuses on the body of work exploring VT and STS within staff groups working exclusively with people who have perpetrated offences. The search question was: 'What is known about the prevalence and development of STS/VT for staff working with offending populations?' As yet, there have been no literature reviews conducted within this area. The aim of this review was to provide clearer insight into the prevalence and development of VT and STS within any staff groups working with offender populations and provide an appraisal of study quality. This is important because gaining a better understanding of VT and STS and its impact upon staff working with populations of offenders could lead to insights regarding required intervention.

The lack of conceptual clarity for VT and STS within the literature base makes this a challenging area to review. Several of the studies state that they are measuring VT but use measures which are designed to assess STS. For the purpose of the current review, where possible, the results from the included studies will be categorised as measuring VT or STS based upon the measures used, rather than what the study states it is measuring.

\section{$\underline{\text { Method }}$}

A systematic strategy was utilised for this literature review. The literature search was completed in May 2019. No start date was specified. The lead author conducted the literature search, abstract screening and critical appraisal of studies. The key terms used to conduct this search were "vicarious trauma" or "secondary trauma" and "offenders". A thesaurus was used to identify related terms. The full search string is shown in Box 1. 
Box 1: Literature review search terms.

("vicarious trauma*" OR "secondary trauma*" OR "compassion fatigue") AND (criminal OR perpetrat* OR correction* OR penal OR prison OR custodial OR forensic OR offend*)

The electronic database searches were carried out using the EBSCOhost to search the following databases: Cumulative Index to Nursing and Allied Health Literature (CINAHL), Medline, PsycInfo, and PsycArticles. Scopus was searched additionally. Reference lists, citing articles, Google Scholar and related reviews were hand searched to identify any omitted articles and to check for publication bias. One unpublished dissertation was identified which would have been included, had it been peer reviewed (Thomas, 2012).

\section{Inclusion Criteria}

To be included in this literature review, studies must have met the following criteria:

1. Published in English due to a lack of translation resources.

2. Peer reviewed.

3. Participants must be staff working directly and primarily with adult offenders, as assessed by examination of the reported sample characteristics for each study. Adult offenders have been specified because the management of juvenile offenders reportedly differs significantly (Richards, 2011), which may have implications for the development of VT/STS.

4. Focus of the study must be on secondary traumatic stress or vicarious trauma. 


\section{Exclusion Criteria}

1. Participants have regular contact with survivors of crime (e.g. police, judges), meaning if the staff reported VT/STS, it would be unclear if it was due to their work with survivors or offenders.

2. Participants do not have direct contact with offenders e.g. admin staff, internet child abuse investigators.

3. Paper is a summary or opinion piece.

\section{Search Outcome}

Eleven studies were identified to be included within this review. Of these studies, seven utilised a quantitative design, three a qualitative design and one study took a mixed methods approach. Each study is described briefly below; further details can be found in Table One.

Please refer to Figure 1 for a flow chart detailing the literature search process.

\section{INSERT FIGURE 1}

\section{Critical Appraisal}

The quantitative studies included in this review all utilised a cross-sectional design. The AXIS tool was used to critically appraise these papers because it was specifically designed to report on quality and risk of bias in cross-sectional studies (Downes et al., 2016). The qualitative papers were critically appraised using the CASP Qualitative Checklist (Critical Appraisal Skills Programme, 2018). One study utilised both qualitative and 
quantitative methodology (Hatcher \& Noakes, 2010) and was assessed using the CASP and the AXIS tool. The CASP and the AXIS tools score each item: two if the criterion is fully met, one if it is partially met or zero if it is not met or indiscernible. Quality scores for each included study can be reviewed in Tables Two and Three. Based upon these scores, the key strengths and limitations of each study have been highlighted in Table 1 and synthesised within the study quality section of the results.

\section{$\underline{\text { Results }}$}

\section{Overview of Included Studies}

Bell et al. (2019) quantitatively investigated the link between workplace trauma exposure and other risk and protective factors for STS, in 36 nurses and correctional officers. Staff were based in mental healthcare areas of one prison. Participants were identified from admin records and a STS questionnaire was distributed directly to them.

The prevalence of STS in 277 probation/parole officers and residential officers working in community correctional services was explored by Rhineberger-Dunn et al. (2016). They recruited by contacting district directors of correctional departments and requesting them to forward an email containing an anonymised survey link to their staff. The survey included a STS self-report measure and demographic questions.

Hatcher and Noakes (2010) took a mixed methods approach to evaluating STS and its associations with demographic and work-related variables, within a sample of 48 multidisciplinary staff providing interventions to sexual offenders across prison and community settings. A national sample was recruited by questionnaire packs being 
distributed to those known personally to researchers and by a contact person within each correctional agency.

Experiences of STS and approaches to coping were reported on following seven focus groups, which included 49 parole officers and supervising officers with sex offenders on their caseloads (Severson \& Pettus-Davis, 2013).

Twenty counsellors specialising in substance dependency treatment in prison and community settings completed an STS self-report measure, and attended individual semistructured interviews focussed on STS, in Perkins and Sprang's (2013) study. Participants were recruited via "professional referral" at each site, before proceeding with snowball sampling. Participants additionally completed quantitative measures of STS and empathy.

Steed and Bicknell (2001) quantitatively explored the presence of STS and its associations with level of training in 67 multidisciplinary therapists, working with sexual offenders. It is stated that questionnaires were distributed to all eligible participants in Australia.

A study used quantitative measures to investigate the relationship between therapists' STS levels and perceptions of the working alliance with male sexual offender clients (Carmel \& Friedlander, 2009). The sample consisted of 106 therapists working in a variety of settings (e.g. correctional facilities, inpatient hospitals). Recruitment was via those known personally to the researchers and by a letter mailed twice to 500 members of the Association for the Treatment of Sexual Abusers. 
Kadambi and Truscott (2003) investigated factors that might predict or mitigate VT and STS within their sample of 91 therapists, providing interventions to sexual offenders. Surveys containing a questionnaire developed by the researchers and two STS measures were mailed to potential participants.

The associations between attachment styles and VT were quantitatively investigated by Merhav et al. (2018) in a sample of 189 probation officers. All probation officers in Israel were contacted by mail and invited to participate. VT was measured using the trust and safety subscales of the Trauma and Attachment Belief (TABS) Scale (Pearlman, 2003).

Morran (2008) distributed a qualitative questionnaire at a domestic violence practitioners network meeting and electronically to members of that network. The questionnaire was designed by the researchers to inquire about training, support and work experiences; it did not directly assess VT/STS. They gained responses from 30 probation officers and multidisciplinary practitioners working within domestic violence offender programmes.

One study quantitatively explored the existence of STS within a sample of 205 correctional health nurses, working in secure settings (Munger et al., 2015). An STS measure was mailed to 2000 eligible nurses, randomly selected from the National Commission on Correctional Health Care (NCCHC) mailing list.

INSERT TABLE 1 


\section{Design of Studies}

The majority of included studies utilised a quantitative cross-sectional design (Bell et al., 2019; Carmel \& Friedlander, 2009; Kadambi \& Truscott, 2003; Merhav et al., 2018; Munger et al., 2015; Rhineberger-Dunn et al., 2016; Steed \& Bicknell, 2001). One study used a mixed methods concurrent design, whereby the qualitative and quantitative components were conducted simultaneously (Hatcher \& Noakes, 2010). Three studies utilised a qualitative methodology but did not further specify a specific qualitative approach (Morran, 2008; Perkins \& Sprang, 2013; Severson \& Pettus-Davis, 2013).

\section{Participants and Settings}

Participant numbers ranged from 20-277. All of the studies, other than Severson and Pettus-Davis (2013) who did not report their participants' gender, included both male and female participants. The majority of studies included well defined samples of one professional group (e.g. nurses, probation officers, therapists), three studies included multidisciplinary clinicians (Hatcher \& Noakes, 2010; Morran, 2008; Steed \& Bicknell, 2001).

The staff recruited to participate in these studies worked across a variety of settings including: community settings (Rhineberger-Dunn et al., 2016; Severson \& Pettus-Davis, 2013), prison settings (Bell et al., 2019), community and prison settings (Hatcher \& Noakes, 2010; Perkins \& Sprang, 2012) and varied settings (e.g. prisons, private practice, community mental health teams and forensic mental health units; Carmel \& Friedlander, 2009; Munger et al., 2015). 


\section{Measures}

Three self-report measures were used to measure STS by the included studies. The Professional Quality of Life Scale (ProQOL; Figley, 1995; Stamm, 2002, 2005, 2010) contains subscales to measure compassion fatigue (STS), compassion satisfaction and burnout. In the current review, the ProQOL was included by Bell et al. (2019), Hatcher and Noakes (2010), Perkins and Sprang (2013), Carmel and Friedlander (2009), Steed and Bicknell (2001), and Munger et al. (2015). The Secondary Traumatic Stress Scale (STSS; Bride et al., 2004) was utilised by Rhineberger-Dunn et al. (2016). The Impact of Events Scale (IES; Horowitz et al., 1980; Weiss \& Marmar, 1997), measures trauma related difficulties in line with the diagnostic criteria for PTSD. When using the IES to measure STS, participants should respond in reference to their work with clients as the trauma (Bride et al., 2007). Within the current review, Kadambi and Truscott (2003), Steed and Bicknell (2001), Hatcher and Noakes (2010) and Carmel and Friedlander (2009) included the IES.

A commonly used measure of VT is The Trauma and Attachment Belief Scale (TABS; Pearlman, 2003), formerly known as the Traumatic Stress Institute Belief Scale (TSI; Pearlman, 1996). In the current review, the TSI was utilised by Kadambi and Truscott (2003) and the TABS was included by Merhav et al. (2018).

\section{Study Quality (Tables 2 and 3)}

Quality assessment of the included studies highlighted significant weaknesses across a variety of domains. Three studies reported aims to assess VT, however they purely included STS measures, so their methodology was not appropriate to meet their study aims (Kadambi \& Truscott, 2003; Hatcher \& Noakes, 2010; Munger et al., 2015). Morran (2008) did not 
specify any aims and used both the terms VT and STS without clearly defining or differentiating between them.

Transparent recruitment procedures which were largely appropriate to access their desired populations were detailed by six studies (Bell et al., 2019; Hatcher \& Noakes, 2010; Merhav et al., 2018; Morran, 2008; Munger et al., 2015; Rhineberger-Dunn et al., 2016). Hatcher and Noakes (2010), and Carmel and Friedlander (2009) recruited some clinicians personally known to the researchers. This is ethically concerning because these participants may have felt pressured to participate based upon their relationship with the researchers. Perkins and Sprang (2013) paid $£ 30$ incentive to participants which could have influenced their decision to participate and their perception of their ability to withdraw. Three studies provided insufficient detail about recruitment to allow for replication or critique (Kadambi \& Truscott, 2003; Severson \& Pettus-Davis, 2013; Steed \& Bicknell, 2001). Four studies did not specify the setting from which their participants were recruited from (Kadambi \& Truscott, 2003; Merhav et al., 2018; Morran, 2008; Steed \& Bicknell, 2001) and six studies did not specify the population worked with so it is assumed that they were working with perpetrators of any offence (Bell et al., 2019; Merhav et al., 2018; Munger et al., 2015; Perkins \& Sprang, 2013; Rhineberger-Dunn et al., 2016; Severson \& Pettus-Davis, 2013). This is problematic for replicating and generalising their results.

A response rate of $50 \%-60 \%$ or greater is considered optimal for keeping nonresponse bias to an acceptable level (Fincham, 2008). Seven studies reported their recruitment response rates which ranged from $10.1 \%$ to $73.3 \%$ with a mean of $42.74 \%$ (Carmel \& Friedlander, 2009; Hatcher \& Noakes, 2010; Kadambi \& Truscott, 2003; Merhav et al., 2018; Munger et al., 2015; Rhineberger-Dunn et al., 2016; Steed \& Bicknell, 2001). 
Only Merhav et al. (2018) reported a response rate of over 50\%, specifically $73.3 \%$. Kadambi and Truscott (2003) compared the demographic characteristics of their sample against the population of sex offender therapists in Canada and found them to be representative. For the remaining studies, it is unknown if their recruited sample was representative of their target population, which limits external validity. None of the included studies provided information about how many participants withdrew at any stage during the research, meaning it could not be assessed if the studies were impacted by attrition bias.

For qualitative research to be considered rigorous it should demonstrate trustworthiness which is often judged by the truth value, applicability, consistency and neutrality of the research (Guba, 1981; Krefting, 1991). All three of the included studies which utilised a qualitative methodology did not further specify a specific qualitative design (Morran, 2008; Perkins \& Sprang, 2013; Severson \& Pettus-Davis, 2013). This is problematic because using a scientific method to provide evidence based guidelines for gathering, evaluating and reporting information is central to scientific research (Cozby, 1993; Marczyk et al., 2005).

Morran (2008) gave no indication of how their data were analysed, reducing the replicability and reliability of their study. The qualitative studies did not reflect upon the role of the researcher and the bias they hold. This means the impact of researcher bias on the results cannot be assessed, reducing credibility. Perkins and Sprang (2013) and Severson and Pettus-Davis (2013) increased reliability by crosschecking their data analysis using multiple researchers. 
All nine quantitative studies included well established measures to assess VT and STS. Self-report measures were relied exclusively upon, which can be vulnerable to subjectivity and social desirability bias, potentially affecting their reliability, though they are widely used in research. The ProQOL is the most commonly used measure of STS (Bride et al., 2007; Nimmo \& Huggard, 2013). Reasonable psychometric properties have been concluded for the ProQOL, with the exception of the burnout and STS subscales demonstrating low convergent validity (Hemsworth et al., 2018). The STSS was designed to parallel the DSM-IV-TR (American Psychiatric Association, 2000) criteria for PTSD and has reported appropriate psychometric properties to measure STS (Bride et al., 2004). The IES was designed to measure direct experiences of trauma but it has also been regularly used to assess STS. The reliability and validity of using the IES to measure STS has not been fully established (Bride et al., 2007). The TABS/TSI was designed to be used with those who have experienced trauma and is commonly used to assess VT (Nimmo \& Huggard, 2013). Kadambi and Truscott (2003) expressed concerns that the TSI measure had limited construct validity due to it being highly correlated with a burnout measure. Merhav et al. (2018) used the trust and safety subscales from the TABS to report on VT. It was unclear why the subscales of control, intimacy and esteem were omitted, meaning all of the components of VT were not represented. Due to this, their results will not be presented in the below findings.

None of the quantitative studies included a power analysis to demonstrate that their sample was sufficient to detect effects in their analysis and thus is a limitation in terms of interpreting their results. The studies by Bell et al. (2019), Hatcher and Noakes (2010), and Steed and Bicknell (2001) reflected in their discussions that their studies were underpowered, potentially explaining their lack of significant findings. 
INSERT TABLE 2

INSERT TABLE 3

\section{Main Findings}

As demonstrated in Tables Two and Three, the appraisal process revealed that several of the studies in this review had deficits in the quality of their design. This makes it challenging to draw firm conclusions from the findings.

\section{Prevalence of Secondary Trauma}

All studies quantitatively assessing secondary traumatic stress (STS) reported it to be present within their samples. Five studies classified their sample as being within the range of low to moderate levels of STS (Bell et al., 2019; Carmel \& Freidlander, 2009; Hatcher \& Noakes, 2010; Munger et al., 2015; Rhineberger-Dunn et al., 2016). Steed and Bicknell (2001) and Kadambi and Truscott (2003) respectively found $46.2 \%$ and $24 \%$ of their participants fell within the moderate to high risk ranges for STS. Both of their samples were working with sexual offenders. Of their twenty participants, Perkins and Sprang (2013) found nine counsellors scored highly for STS and three scored low. They do not state how the remainder of the sample scored, so mid ranges are assumed. Within each of Severson and Pettus-Davis's (2013) focus groups, parole officers spontaneously described experiencing emotional reactions towards their work consistent with the effects of STS. Including "somatic reactions, disrupted sex lives, pervasive thoughts, a loss of innocence, and hypervigilance in both their work and personal lives" (p. 16).

No studies reported levels of vicarious trauma (VT) within their samples. Kadambi and Truscott (2003) did not report mean levels of VT, however, they stated there were no 
significant differences between their sample and a criterion reference group of mental health professionals, regarding levels of VT. This suggests levels of VT may be similar between professionals working with offending and non-offending populations. Themes indicative of VT were identified within the samples of three qualitative studies, these included, feeling less safe in the world (Hatcher \& Noakes, 2010; Morran, 2008) and becoming more suspicious about the intentions of others (Hatcher \& Noakes, 2010; Severson \& Pettus-Davis, 2013).

\section{Factors influencing the development of STS/VT}

Whilst working in a prison environment, Bell et al. (2019) found that all staff had witnessed or experienced a high frequency of traumatic events including: prisoner self-harm or suicide attempts, assaults of colleagues and verbal abuse/threats. They also found that a personal assault at work requiring medical intervention had been experienced by $57 \%$ of mental health staff and 53\% of correctional officers. Bell et al. (2019) stated that traumatic events had a negative impact on STS but did not report results relating to this, which limits what can be concluded with confidence. High levels of exposure to violence when working in secure settings (67\%) were also found by Munger et al. (2015), with nearly a third of those exposed scoring at high risk for STS, and another third scoring at moderate risk. It appeared that nurses who were at the lowest risk of STS had not been exposed to violence; however, more than $60 \%$ of those not exposed to violence were still categorised as being at moderate risk of STS. Perceived level of exposure to client traumatic material was not found to be significantly related to VT by Kadambi and Truscott (2003).

Kadambi and Truscott (2003) had planned to investigate the impact of therapists' personal history of sexual abuse/assault on VT, but as only eight out of 91 people reported this history, it could not be statistically explored. They noted, based on mean scores, that 
therapists with a trauma history appeared to score higher for VT than those without a trauma history. Rhineberger-Dunn et al., (2016) found no significant associations between STS and military veteran status, which they concluded to mean that past trauma may not be relevant to experiences of STS.

Perkins and Sprang (2013) identified that substance abuse counsellors working with offending populations who were personally in recovery from substance misuse difficulties, or had family members struggling with addiction, were more vulnerable to experiencing STS.

Informal support systems, such as talking with colleagues about the personal impact of work, were identified as an important protective factor against STS and VT by Bell et al. (2019), Kadambi and Truscott (2003) and Severson and Pettus-Davis (2013). Two studies found that little formal support or training existed to assist staff with preventing or managing secondary trauma reactions (Morran, 2008; Perkins \& Sprang, 2013). Severson and PettusDavis (2013) reported concern that support from management is insufficient, and sometimes detrimental. Participants detailed management breaching their confidentiality, placing them in isolated rural locations and holding poor attitudes towards sexual offenders. Interestingly, two studies quantitatively found frequency of supervision and organisational support not to be significantly associated with STS or VT (Hatcher \& Noakes, 2010; Kadambi \& Truscott, 2003). Bell et al. (2019) found support from management and feeling adequately skilled to be significantly associated with lower levels of STS. These differences may be explained by the quality of supervisory support being received, with high quality supervision protecting staff from STS and poorer quality supervision having no impact upon STS. 
Rhineberger-Dunn et al. (2016) found parole officers and residential officers were less likely to report STS if they had better general health, training which they perceived to prepare them adequately for the job, and fewer hours directly working with offenders. Fewer contact hours with offenders was not found to be associated with VT by Kadambi and Truscott (2003). The use of humour and repression of details of client's offences were discussed as coping mechanisms against STS/VT within Severson and Pettus-Davis's (2013) study. Further, Hatcher and Noakes (2010) demonstrated that role problems, such as being given conflicting or ambiguous job demands, predicted increased STS in staff working with sexual offenders. Investigation of the relationship between therapists' levels of STS and their perception of the working alliance between themselves and their clients, demonstrated no significant associations (Carmel \& Friedlander, 2009).

Steed and Bicknell (2001) noted that social workers were at significantly higher risk than psychologists for STS within their sample, and Rhineberger-Dunn et al. (2016) found that the level of STS was higher in probation/parole officers than residential officers. Job role was not found to be a significant factor by Hatcher and Noakes (2010).

Studies which included participants' age within their analysis did not find any significant associations between age and STS or VT (Carmel \& Friedlander 2009; Hatcher \& Noakes, 2010). Several studies explored whether the gender of participants impacted upon STS or VT and found no significant associations or differences (Carmel \& Freidlander, 2009; Hatcher \& Noakes, 2010). Morran (2008), however, concluded from their qualitative study that the emotional consequences linked to VT for female staff working with male perpetrators of domestic violence were considerably higher than for male staff. Female staff reported anger towards clients, concern for physical and emotional safety, and hyper-awareness of 
power issues in personal relationships. These gender differences appear specific to this client population.

No significant associations were found in investigations of length of time working with sexual offenders (Steed \& Bicknell, 2001) or years of general experience and levels of STS/VT (Carmel \& Friedlander, 2009; Kadambi \& Truscott, 2003; Steed \& Bicknell, 2001).

Two studies found no significant differences in levels of STS dependent upon where staff were located, including prison settings or community locations (Hatcher \& Noakes, 2010; Perkins \& Sprang, 2013).

\section{$\underline{\text { Discussion }}$}

This literature review examined eleven research papers assessing secondary traumatic stress (STS) and/or vicarious trauma (VT) experienced by professionals working with offender populations. Conceptual difficulties meant that studies were categorised for this review as assessing VT or STS based on the measures they used rather than what they stated they were investigating. Studies within this review were predominantly exploring STS, with only two studies quantitatively assessing VT. Few conclusions can therefore be drawn from this review about VT within professionals working with offending populations.

Overall, these studies demonstrated that STS and VT do exist within a variety of staff working with offending populations, though the findings varied regarding the levels to which STS was present, with most demonstrating low to medium risk. No studies reported the levels of VT within their sample. Kadambi and Truscott (2003) compared the levels of VT within 
their sample of sex offender therapists against a criterion reference group of mental health professionals and found them not to differ. This is consistent with previous findings suggesting levels of VT do not differ between staff working with offenders or survivors of crime (Way et al., 2004). Studies utilising qualitative methods identified themes consistent with experiences of VT for staff working with perpetrators of domestic violence and sexual offenders (Morran, 2008; Severson \& Pettus-Davis, 2013).

A variety of protective factors were associated with STS for staff including: informal support (Bell et al., 2019; Rhineberger-Dunn et al., 2016), fewer direct contact hours with offenders, better general health, adequate training (Rhineberger-Dunn et al., 2016), and repression of the details of client offences (Severson \& Pettus-Davis, 2013). It was identified that managerial support was often felt to be lacking (Morran, 2008; Perkins \& Sprang, 2013; Severson \& Pettus-Davis, 2013). Informal support was identified as a protective factor against developing VT (Kadambi \& Truscott, 2003; Severson \& Pettus-Davis, 2013). There were some inconsistencies found in relation to if managerial/supervisory support was a significant protective factor against STS and VT, these discrepancies may be explained by the quality of support which was being received within the different samples. Research focussed upon staff working with non-offending survivors of trauma also concluded social support, work support (Hensel et al., 2015) and supervision (Baird \& Kracen, 2006) to be protective against STS and VT. Demographic factors were found to have little influence on levels of STS and VT, which is consistent with the literature on staff working with survivor populations (Hensel et al., 2015).

The literature base has consistently found trauma history to increase a professionals' risk of developing VT or STS (Baird \& Kracen, 2006; Hensel et al., 2015). Two studies in 
this review demonstrated that staff working with offenders are frequently exposed to traumatic events in the workplace and suggested this links to higher risk of STS (Bell et al., 2019; Munger et al., 2015). Methodological limitations meant that no conclusions on the relationship between personal trauma history and STS or VT could be drawn and should be explored further.

When interpreting these findings, there are several factors which should be considered. As previously highlighted, the studies involved staff from different occupational groups, working in different settings with offenders who had committed a variety of crimes, and were conducted in several countries. It has been suggested that the sociocultural context can be influential in shaping emotional experiences and processing following trauma exposure (Bracken, 2001; Marshall \& Suh, 2003). Factors found to be influential to the development of VT/STS such as social resources, organisational characteristics and existing policies are likely to differ across countries (Voss Horrell et al., 2011). This variation meant that direct comparison of studies conducted in various countries within this review is problematic. Further, several studies reported low response rates. It is currently unknown what deters non-responders from participating and what impact this may have had on the results. Those who are distressed may be engaging in avoidant coping and be unlikely to participate, leading to an under-representation in research. Or alternatively, those experiencing STS/VT may be drawn to participate in the research and be over-represented.

The difficulties with conceptualising STS have sequentially led to multiple STS measures being created. Hatcher and Noakes (2010) found that scoring on STS measures, the ProQOL and IES, did not correlate within their sample. The ProQOL tends towards inclusion (Stamm, 1995) whilst PTSD measures, such as the IES, may be overly stringent (Motta et al., 
1997) because STS is considered less severe than PTSD from direct exposure to trauma (Lerias \& Byrne, 2003). Different approaches to measurement are one explanation for why the levels of STS fluctuate within the samples. It is felt that future studies should aim to include measures which have been specifically designed and validated to measure STS, such as the STSS (Bride et al., 2004) and the ProQOL (Stamm, 2002).

As demonstrated by Tables Two and Three, many of the studies included within this review were lacking in quality in areas of their design, which makes it challenging to draw firm conclusions from the studies. Key issues which have been discussed included small sample sizes leading to underpowered studies, low response rates, lack of clearly defined samples, lack of transparency around recruitment and qualitative approach utilised. It is also a concern that ethnic minority groups appeared under-represented within the studies which may have implications for generalisability.

\section{Limitations of Review}

Whilst interpreting the results, the limitations of this literature review should be taken into consideration. The limited number of papers included is reflective of the small amount of research that has been conducted within this area and thus drawing conclusions from a small amount of literature is challenging. As previously noted, the lack of homogeneity between areas of the included studies increases the difficulty in drawing conclusions. Whilst a narrow focus was deemed necessary, it is thought that including research investigating similar and related topics, such as, countertransference reactions, PTSD and burnout could have added beneficial findings to this literature review. The search strategy was designed with the intention to capture the eligible literature, but it is possible that had more terms and databases been utilised that additional relevant papers could have been found. It would have been 
desirable to have more than one reviewer conducting the literature search, critical appraisal and synthesis in order to reduce subjectivity and increase reliability of the review.

As previously outlined, there are conceptual issues both within the studies included in this review and the wider literature base regarding VT and STS. The terms were often overlapped or used incorrectly. Inspection of the measures utilised by the included studies demonstrated only two to be quantitatively assessing VT, and one of these studies used the measure incorrectly. It therefore may have been beneficial to omit the VT papers and focus the review on STS. This review combined the terms compassion fatigue and STS as they are widely considered different terms for the same phenomena. There is, however, some evidence to indicate that they differ regarding their content validity (Jenkins \& Baird, 2002) and Stamm (2010) has begun separating the constructs within her work. This suggests that it may have been desirable to separate compassion fatigue from STS. Conversely, due to the similarities between the concepts, referring to VT, STS and compassion fatigue under an umbrella term of 'secondary trauma' for this review may have been sufficient and more coherent.

Secondary trauma can be challenging to differentiate from direct trauma as definitions and symptoms are similar (American Psychiatric Association, 2013; Figley, 2002). Staff working within forensic services are frequently exposed to trauma directly (e.g. violence) and in-directly (e.g. client material, self-harm), this makes it difficult to untangle if the trauma responses being measured are attributable to secondary or direct trauma. These challenges are also present within STS measures, such as the IES and ProQOL, which include questions assessing hyperarousal (e.g. 'I was jumpy and easily startled) which could be attributable to secondary or direct trauma. It would be beneficial for future studies to control for direct 
trauma in the analysis and be explicit about how secondary trauma is being defined (e.g. focussing upon staff reactions to client material).

\section{Considerations for Practise and Future Directions}

Moving forwards, it would be desirable for research to use accurate definitions of VT and STS and utilise the appropriate measurement tools for each of these concepts. Research assessing VT was particularly lacking, as most studies which aimed to investigate VT purely included measurements for STS, likely due to a lack of conceptual clarity. Further research including validated measures of VT, such as The Trauma and Attachment Belief Scale (Pearlman, 2003), is required within staff groups working with offending populations.

Research in this area is still in its infancy, and most studies have focused on therapists or other clinical staff who are trained in managing the emotional impact of the work they do. Preliminary results have suggested that the prevalence of STS varies between staff groups, with those with less training appearing to experience higher levels of STS (RhinebergerDunn et al., 2016; Steed \& Bicknell, 2001). More research should be conducted with nonclinical staff, such as custodial staff and support workers. These staff groups are underrepresented in the literature and may be more vulnerable to STS than therapists, due to them receiving less training and supervision. Additional research is required in order to further explore and understand the reasons for these differences in STS between groups of professionals, in order to inform intervention opportunities. Staff with less training may require additional STS psychoeducation and/or support.

It has been suggested that such studies as those included in this review may be impacted by attrition bias (Hatcher \& Noakes, 2010), whereby those experiencing VT/STS 
leave the job and are thus not included in research samples. To test this, experiences of STS/VT should be examined in professionals who have left a role working with offenders, where possible. This could be done via research of a longitudinal design or by advertising widely to recruit professionals who have left a role working with offenders.

All the included studies were cross-sectional, so causation cannot be implied, though it should be noted that this was not the aim of these research studies. VT has been described as causing long term changes to how individuals view the world (Moulden \& Firestone, 2007), therefore, longitudinal research in the area would be beneficial to capture more information about the developmental trajectory of VT. It would also be helpful to enquire about the work history of participants to help ascertain if experiences of VT or STS developed prior to their current role, for example, whilst working with trauma survivors.

Where services are unable to protect staff from being secondarily exposed to trauma, they should aim to support staff before and after trauma exposure in an attempt to mitigate the effects (Bell et al., 2019). It was frequently reported that informal support networks where professionals felt safe and able to talk through the personal impact of the work helped to reduce STS and VT. Peer supervision and other informal communications between colleagues should therefore be encouraged within services. Staff working with offender populations require adequate support from managers and supervisors in order to cope with the emotional impact of the work. Several studies reported that this support could be improved by managers/supervisors: ensuring regular supervision, showing interest in and appreciation for work undertaken with offenders, consulting staff before making changes and avoiding being overly preoccupied with targets. The results also indicated that staff are less vulnerable to developing STS/VT when they have been supported by training to ensure they 
feel competent and skilled in their work. Service providers should be aware that staff working with offending populations can be vulnerable to negative effects from being secondarily exposed to trauma, and consider offering trauma psychoeducation and STS/VT interventions where necessary. Promoting trauma informed care within services which work with offending populations is likely to ensure more enabling environments for service users whilst ensuring appropriate organisational support for staff (Levenson \& Willis, 2019).

\section{Conclusions}

Issues with incorrect use of terminology and flawed methodology within these papers made it a challenging area to review, these limitations should be held in mind when interpreting the results. Despite these issues, it was consistently reported that secondary traumatic stress or vicarious trauma are present within populations of staff working with offenders. Most studies concluded that STS was present at a low to moderate level, suggesting that the majority of staff working with offending populations are not impacted by STS. No studies reported prevalence rates for VT. This still highlights a need for service providers to consider the impact of being secondarily exposed to trauma on professionals and promote supportive working environments, including opportunities for peer support and highquality supervision. The secondary trauma literature should give similar attention to both staff working with offending populations and staff working with trauma survivors. Additional research is required in this area to draw firm conclusions. 


\section{$\underline{\text { References }}$}

American Psychiatric Association. (2000). Diagnostic and statistical manual of mental disorders (4th ed.). American Psychiatric Association.

American Psychiatric Association. (2013). Diagnostic and Statistical Manual of Mental Disorders (5th ed.). American Psychiatric Publishing.

Armstrong, G. S., \& Griffin, M. L. (2004). Does the job matter? Comparing correlates of stress among treatment and correctional staff in prisons. Journal of Criminal Justice, 32(6), 577-592. https://doi.org/10.1016/j.jcrimjus.2004.08.007

Baird, K., \& Kracen, A. C. (2006). Vicarious traumatization and secondary traumatic stress: A research synthesis. Counselling Psychology Quarterly, 19(2), 181188. https://doi.org/10.1080/09515070600811899

Beck, C. T. (2011). Secondary traumatic stress in nurses: A systematic review. Archives of Psychiatric Nursing, 25(1), 1-10. https://doi.org/10.1016/j.apnu.2010.05.005

Bell, S., Hopkin, G., \& Forrester, A. (2019). Exposure to traumatic events and the experience of burnout, compassion fatigue and compassion satisfaction among prison mental health staff: an exploratory survey. Issues in Mental Health Nursing, 40(4), 304-309. https://doi.org/10.1080/01612840.2018.1534911

Bercier, M. L., \& Maynard, B. R. (2015). Interventions for secondary traumatic stress with mental health workers: A systematic review. Research on Social Work Practice, 25(1), 81-89. https://doi.org/10.1177/1049731513517142

Berg, M. T., Stewart, E. A., Schreck C. J., \& Simons, R. L. (2012). The victim-offender overlap in context: Examining the role of neighbourhood street culture. Criminology, 50(2), 359-390. https://doi.org/10.1111/j.1745-9125.2011.00265.x

Bracken, P. J. (2001). Post-modernity and post-traumatic stress disorder. Social Science \& Medicine, 53(6), 733-743. https://doi.org/10.1016/S0277- 9536(00)00385-3

Brennan, K. A., Clark, C. L., \& Shaver, P. R. (1998). Self-report measurement of adult attachment: An Integrative overview. In Simpson, J. A. \& Rholes, W. S. (Eds.), Attachment Theory and Close Relationships (pp. 46-76). Guilford Press.

Bride, B. E. (2007). Prevalence of secondary traumatic stress among social workers. Social Work, 52(1), 63-70. https://doi.org/10.1093/sw/52.1.63

Bride, B. E., \& Figley, C. R. (2009). Secondary trauma and military veteran caregivers. Smith College Studies in Social Work, 79(3-4), 314-329. https://doi.org/10.1080/00377310903130357 
Bride, B. E., Radey, M., \& Figley, C. R. (2007). Measuring compassion fatigue. Clinical Social Work Journal, 35(3), 155-163. https://doi.org/10.1007/s10615-007-0091-7

Bride, B. E., Robinson, M. M., Yegidis, B., \& Figley, C. R. (2004). Development and validation of the secondary traumatic stress scale. Research on Social Work Practice, 14(1), 27-35. https://doi.org/10.1177/1049731503254106

Broderick, C., Azizian, A., Kornbluh, R., \& Warburton, K. (2015). Prevalence of physical violence in a forensic psychiatric hospital system during 2011-2013: Patient assaults, staff assaults, and repeatedly violent patients. CNS spectrums, 20(3), 319-330. https://doi.org/10.1017/S1092852915000188

Canfield, J. (2005). Secondary traumatization, burnout, and vicarious traumatization: A review of the literature as it relates to therapists who treat trauma. Smith College Studies in Social Work, 75(2), 81-101. https://doi.org/10.1300/J497v75n02_06

Carlson, E. B., Smith, S. R., Palmieri, P. A., Dalenberg, C., Ruzek, J. I., Kimerling, R., Burling, T. A., \& Spain, D. A. (2011). Development and validation of a brief self-report measure of trauma exposure: The trauma history screen. Psychological Assessment, 23(2), 463-77. https://doi.org/10.1037/a0022294

Carmel, M. J. S., \& Friedlander, M. L. (2009). The relation of secondary traumatization to therapists' perceptions of the working alliance with clients who commit sexual abuse. Journal of Counseling Psychology, 56(3), 461-467. https://doi.org/10.1037/a0015422

Caruso, D. R., \& Mayer, J. D. (1998). A measure of emotional empathy for adolescents and adults [Unpublished Manuscript]. Scholars' Repository. University of New Hampshire.

Cieslak, R., Shoji, K., Douglas, A., Melville, E., Luszczynska, A., \& Benight, C. C. (2014). A meta-analysis of the relationship between job burnout and secondary traumatic stress among workers with indirect exposure to trauma. Psychological Services, 11(1), 75. https://doi.org/10.1037/a0033798

Cocker, F., \& Joss, N. (2016). Compassion fatigue among healthcare, emergency and community service workers: A systematic review. International Journal of Environmental Research and Public Health, 13(6), 1-18. https://doi.org/10.3390/ijerph13060618

Collins, J. J., \& Bailey, S. (1990). Traumatic stress disorder and violent behaviour. Journal of Traumatic Stress, 3, 203-220. https://doi.org/10.1007/BF00975146 Cozby, P. C. (1993). Methods in behavioral research (5th ed.). Mayfield Publishing Co. 
Craig, C., \& Sprang, G. (2010). Compassion satisfaction, compassion fatigue, and burnout in a national sample of trauma treatment therapists. Anxiety, Stress, and Coping, 23(3), 319-339. https://doi.org/10.1080/10615800903085818

Creamer, T. L., \& Liddle, B. J. (2005). Secondary traumatic stress among disaster mental health workers responding to the September 11 attacks. Journal of Traumatic Stress, 18(1), 89-96. https://doi.org/10.1002/jts.20008

Crisford, H., Dare, H. \& Evangeli, M. (2008). Offence-related posttraumatic stress disorder (PSTD) symptomatology and guilt in mentally disordered violent and sexual offenders. The Journal of Forensic Psychiatry and Psychology, 19(1), 86-107. https://doi.org/10.1080/14789940701596673

Critical Appraisal Skills Programme (2018). CASP Qualitative Checklist. https://caspuk.net/wp-content/uploads/2018/01/CASP-Qualitative-Checklist-2018.pdf.

Downes, M. J., Brennan, M. L., Williams, H. C., \& Dean, R. S. (2016). Development of a critical appraisal tool to assess the quality of cross-sectional studies (AXIS). BMJ Open, 6(12), 1-7. https://doi.org/10.1136/bmjopen-2016- 011458

Figley, C. R. (1995). Compassion fatigue as secondary traumatic stress disorder: An overview. In C. R. Figley (Ed.), Compassion fatigue: Coping with secondary traumatic stress disorder in those who treat the traumatised (pp. 1-20). BrunnerRoutledge.

Figley, C. R. (Ed.). (2002). Treating compassion fatigue. Brunner-Routledge.

Fincham, J. E. (2008). Response rates and responsiveness for surveys, standards, and the Journal. American Journal of Pharmaceutical Education, 72(2), 43-45. https://doi.org/10.5688/aj720243

Friel, A., White, T., \& Hull, A. (2008). Posttraumatic stress disorder and criminal responsibility. The Journal of Forensic Psychiatry \& Psychology, 19(1), 64- 85. https://doi.org/10.1080/14789940701594736

Gentry, J. E., Baranowsky, A. B., \& Dunning, K. (2002). ARP: The Accelerated Recovery Program (ARP) for compassion fatigue. In C. R. Figley (Ed.), Treating compassion fatigue (pp. 123-137). Brunner-Rutledge.

Gray, N. S., Carman, N. G., Rogers, P., MacCulloch, M. J., Hayward, P., \& Snowden, R. J. (2003). Post-traumatic stress disorder caused in mentally disordered offenders by the committing of a serious violent or sexual assault. The Journal of Forensic Psychiatry \& Psychology, 14(1), 27-43. https://doi.org/10.1080/1478994031000074289 
Guba, E. G. (1981). Criteria for assessing the trustworthiness of naturalistic inquiries. Educational Resources Information Centre Annual Review Paper, 29(2), 75-91. doi.org/10.1007/BF02766777

Hatcher, R., \& Noakes, S. (2010). Working with sex offenders: The impact on Australian treatment providers. Psychology, Crime and Law, 16(1-2), 145-167. https://doi.org/10.1080/10683160802622030

Hemsworth, D., Baregheh, A., Aoun, S., \& Kazanjian, A. (2018). A critical enquiry into the psychometric properties of the professional quality of life scale (ProQol-5) instrument. Applied Nursing Research, 39, 81-88. https://doi.org/10.1016/j.apnr.2017.09.006

Hensel, J. M., Ruiz, C., Finney, C., \& Dewa, C. S. (2015). Meta-analysis of risk factors for secondary traumatic stress in therapeutic work with trauma victims. Journal of Traumatic Stress, 28(2), 83-91. https://doi.org/10.1002/jts.21998

Horowitz, M.J., Wilner, N., \& Alvarez, W. (1980). Signs and symptoms of post- traumatic stress disorder. Archives of General Psychiatry, 37(1), 85-92. https://doi.org10.1001/archpsyc.1980.01780140087010

Horvath, A. O., \& Greenberg, L. S. (1989). Development and validation of the Working Alliance Inventory. Journal of counseling psychology, 36(2), 223-233. https://doi.org/10.1037/0022-0167.36.2.223

Huggard, P., Law, J., \& Newcombe, D. (2017). A systematic review exploring the presence of Vicarious Trauma, Compassion Fatigue, and Secondary Traumatic Stress in Alcohol and Other Drug Clinicians. Australasian Journal of Disaster \& Trauma Studies, 21(2), 65-72.

Isenhardt, A., \& Hostettler, U. (2020). Inmate violence and correctional staff burnout: The role of sense of security, gender, and job characteristics. Journal of interpersonal violence, 35(1-2), 173-207. https://doi.org/10.1177/0886260516681156

Jenkins, S. R., \& Baird, S. (2002). Secondary traumatic stress and vicarious trauma: A validational study. Journal of Traumatic Stress, 15(5), 423-432. https://doi.org10.1023/A:1020193526843

Jennings, W. G., Piquero, A. R., \& Reingle, J. M. (2012). On the overlap between victimization and offending: A review of the literature. Aggression and Violent Behavior, 17(1), 16-26. https://doi.org/10.1016/j.avb.2011.09.003 
Jennings, W. G., Zgoba, K. M., Maschi, T., \& Reingle, J. M. (2014). An empirical assessment of the overlap between sexual victimization and sex offending. International Journal of Offender Therapy \& Comparative Criminology, 58(12), 1466-1480. https://doi.org/10.1177/ 0306624x13496544

Kadambi, M. A., \& Truscott, D. (2003). Vicarious traumatization and burnout among therapists working with sex offenders. Traumatology, 9(4), 216-230. https://doi.org/10.1177/153476560300900404

Krefting, L. (1991). Rigor in qualitative research: The assessment of trustworthiness. American Journal of Occupational Therapy, 45(3), 214-222. https://doi.org/10.5014/ajot.45.3.214

Lauritsen, J. L., \& Laub, J. H. (2007). Understanding the link between victimization and offending: New reflections on an old idea. In M. Hough \& M. Maxfield (Eds.), Surveying Crime in the 21st Century (pp. 55-75). Criminal Justice Press.

Lerias, D., \& Byrne, M. K. (2003). Vicarious traumatization: symptoms and predictors. Stress and Health, 19(3), 129-138. https://doi.org/10.1002/smi.969

Levenson, J. S., \& Willis, G. M. (2019). Implementing trauma-informed care in correctional treatment and supervision. Journal of Aggression, Maltreatment \& Trauma, 28(4), 481-501. https://doi.org/10.1080/10926771.2018.1531959

MacNair, R. M. (2002). Perpetration-induced traumatic stress in combat veterans. Peace and Conflict: Journal of Peace Psychology, 8(1), 63-72. https://doi.org/10.1207/S15327949PAC0801_6

Marczyk, G., DeMatteo, D., \& Festinger, D. (2005). Essentials of research design and methodology. John Wiley \& Sons, Inc.

Marshall, R. D., \& Suh, E. J. (2003). Contextualizing trauma: Using evidence-based treatments in a multicultural community after 9/11. Psychiatric Quarterly, 74(4), 401420. https://doi.org/10.1023/A:1026043728263

Maslach, C., Jackson, S. E., \& Leiter, M. P. (1996). Maslach burnout inventory manual. Consulting Psychologists Press.

McCann, I. L, \& Pearlman, L. A. (1990). Vicarious traumatization: A framework for understanding the psychological effects of working with victims. Journal of Traumatic Stress, 3(1), 131-149. https://doi.org10.1002/jts.2490030110

Merhav, I., Lawental, M., \& Peled-Avram, M. (2018). Vicarious traumatisation: Working with clients of probation services. British Journal of Social Work, 48(8), 2215-2234. https://doi.org/10.1093/bjsw/bcx 162 
Morran, D. (2008). Firing up and burning out: The personal and professional impact of working in domestic violence offender programmes. Probation Journal, 55(2), 139-152. https://doi.org10.1177/0264550508090272

Motta, R. W., Joseph, J. M., Rose, R. D. Suozzi, J. M., \& Leiderman, L. J. (1997). Secondary trauma: assessing inter-generational transmission of war experiences with a modified Stroop procedure. Journal of Clinical Psychology, 53(8), 895903. https://doi.org/10.1002/(SICI)1097-4679(199712)53:8\%3C895::AIDJCLP14\%3E3.0.CO;2-F

Moulden, H. M., \& Firestone, P. (2007). Vicarious traumatization: The impact on therapists who work with sexual offenders. Trauma, Violence, and Abuse, 8(1), 67-83. https://doi.org/10.1177/1524838006297729

Munger, T., Savage, T., \& Panosky, D. M. (2015). When caring for perpetrators becomes a sentence: Recognizing vicarious trauma. Journal of Correctional Health Care, 21(4), 365-374. https://doi.org/10.1177/1078345815599976

Nimmo, A., \& Huggard, P. (2013). A systematic review of the measurement of compassion fatigue, vicarious trauma, and secondary traumatic stress in physicians. Australasian Journal of Disaster and Trauma Studies, 2013(1), 37-44. http://tur-www1.massey.ac.nz/ trauma/issues/2013-1/AJDTS_2013-1_Nimmo.pdf

Pearlman, L.A. (1996). Psychometric review of TSI Belief Scale, Revision L. In B. H. Stamm (Ed.), Measurement of stress, trauma, and adaptation, (pp. 415-417). Sidrian Press.

Pearlman, L. A. (2003). Trauma and Attachment Belief Scale. Western Psychological Services.

Pearlman, L., \& MacIan, P. (1995). Vicarious traumatization: An empirical study on the effects of trauma work on trauma therapists. Professional Psychology, Research and Practice, 26(6), 558-565. https://www.nationalcac.org/wp-content/uploads/ 2016/10/Vicarious-traumatization-An-empirical-study-of-the-effects-of-trauma-workon-trauma-therapists.pdf

Perez, L. M., Jones, J., Englert, D. R., \& Sachau, D. (2010). Secondary traumatic stress and burnout among law enforcement investigators exposed to disturbing media images. Journal of Police and Criminal Psychology, 25(2), 113-124. https://doi.org/10.1007/s11896-010-9066-7 
Perkins, E. B., \& Sprang, G. (2013). Results from the Pro-QOL-IV for substance abuse counselors working with offenders. International Journal of Mental Health and Addiction, 11(2), 199-213. https://doi.org/10.1007/s11469-012-9412-3

Pfifferling, J. H., \& Gilley, K. (2000). Overcoming compassion fatigue. Family practice management, 7(4), 39-44. https://www.aafp.org/fpm/2000/0400/p39.html?printable=fpm

Pizarro, J. M., Zgoba, K. M., \& Jennings, W. G. (2011). Assessing the interaction between offender and victim criminal lifestyles and homicide type. Journal of Criminal Justice, 39(5), 367-377. https://doi.org/10.1016/j.jcrimjus.2011.05.002

Rhineberger-Dunn, G., Mack, K. Y., \& Baker, K. M. (2016). Secondary trauma among community corrections staff: An exploratory study. Journal of Offender Rehabilitation, 55(5), 293-307. https://doi.org/10.1080/10509674.2016.1181132

Richards, K. (2011). What makes juvenile offenders different from adult offenders? Trends and Issues in Crime and Criminal Justice, (409), 1-8. https://aic.gov.au/publications/tandi/tandi409

Romey, W. D. (2005). Loyalty: A key concept to understand therapists'symptoms of compassion fatigue and vicarious trauma [Unpublished manuscript], Simon Fraser University. British Colombia.

Rudolph, J. M., Stamm, B. H., \& Stamm, H. E. (1997). Compassion fatigue: A concern for mental health policy, providers, \& administration [Paper presentation]. The Annual Meeting of the International Society for Traumatic Stress Studies, Montreal.

Salston, M., \& Figley, C. R. (2003). Secondary traumatic stress effects of working with survivors of criminal victimization. Journal of Traumatic Stress, 16(2), 167174. https://doi.org/10.1023/A:102289920

Severson, M., \& Pettus-Davis, C. (2013). Parole officers' experiences of the symptoms of secondary trauma in the supervision of sex offenders. International Journal of Offender Therapy and Comparative Criminology, 57(1), 5-24. https://doi.org/10.1177/0306624X11422696

Shoji, K., Lesnierowska, M., Smoktunowicz, E., Bock, J., Luszczynska, A., Benight, C. C., \& Cieslak, R. (2015). What comes first, job burnout or secondary traumatic stress? Findings from two longitudinal studies from the US and Poland. PloS One, 10(8), 115. https://doi.org/10.1371/journal.pone.0136730

Showalter, S. E. (2010). Compassion fatigue: What is it? Why does it matter? Recognizing the symptoms, acknowledging the impact, developing the tools to 
prevent compassion fatigue, and strengthen the professional already suffering from the effects. American Journal of Hospice and Palliative Medicine, 27(4), 239-242. https://doi.org/10.1177\%2F1049909109354096

Stamm, B. H. (Ed.). (1995). Secondary Traumatic Stress: Self-care issues for clinicians, researchers, and educators. Sidran Press.

Stamm, B. H. (Ed.). (1996). Measurement of Stress, Trauma and Adaptation. Sidran Press.

Stamm, B. H. (1997). Work-related secondary traumatic stress. PTSD Research Quarterly. $8(2), 1-7$.

Stamm, B. H. (2002). Measuring compassion satisfaction as well as fatigue: Developmental history of the Compassion Satisfaction and Fatigue Test. In C. R. Figley (Ed.), Treating compassion fatigue (pp. 107-122). Brunner- Routledge.

Stamm, B. H. (2005). The ProQOL Manual: The Professional Quality of Life Scale: Compassion satisfaction, burnout \& compassion fatigue/secondary trauma scales. Sidran Press.

Stamm, B. H. (2010). The concise ProQOL manual (2 ${ }^{\text {nd }}$ Ed.). https://programs. caringsafely.org/wpcontent/uploads/2018/01/ProQOL_Concise_2ndEd_122010.pdf

Steed, L., \& Bicknell, J. (2001). Trauma and the therapist: The experience of therapists working with the perpetrators of sexual abuse. The Australasian Journal of Disaster and Trauma Studies, 1(5), 527-540.

Steiner, H., Garcia, I. G., \& Matthews, Z. (1997). Post-traumatic stress in incarcerated juvenile delinquents. Journal of the American Academy of Child and Adolescent Psychiatry, 36(3), 357-365. https://doi.org/10.1097/00004583-199703000-00014

Thomas, B. (2012). Predictors of vicarious trauma and secondary traumatic stress among correctional officers [Unpublished psychology doctoral dissertation]. Philadelphia College of Osteopathic Medicine.

Thomas, R. B., \& Wilson, J. P. (2004). Issues and controversies in the understanding and diagnosis of compassion fatigue, vicarious traumatization, and secondary traumatic stress disorder. International Journal of Emergency Mental Health, 6(2), 81-92.

VanVoorhis, C. W., \& Morgan, B. L. (2007). Understanding power and rules of thumb for determining sample sizes. Tutorials in quantitative methods for psychology, 3(2), 4350. https://doi.org/10.20982/tqmp.03.2.p043 
Voss Horrell, S. C., Holohan, D. R., Didion, L. M., \& Vance, T. G. (2011). Treating traumatized OEF/OIF veterans: How does trauma treatment affect the clinician? Professional Psychology: Research and Practice, 42, 79-86. https://doi.org/10.1037/a0022297

Watts, J., \& Robertson, N. (2015). Selecting a measure for assessing secondary trauma in nurses. Nurse Researcher, 23(2). https://doi.org/10.7748/nr.23.2.30.s7

Way, I., VanDeusen, K. M., Martin, G., Applegate, B., \& Jandle, D. (2004). Vicarious trauma: A comparison of clinicians who treat survivors of sexual abuse and sexual offenders. Journal of Interpersonal Violence, 19(1), 49-71. https://doi.org/10.1177/0886260503259050

Weiss, D. S., \& Marmar, C. R. (1997). The Impact of Events Scale-Revised. In J. P. Wilson \& T. M. Keane (Eds.), Assessing psychological trauma and PTSD: a Practitioner's Handbook. Guilford. 
Table 1:

Data extracted from the 11 studies included within the literature review

\begin{tabular}{|c|c|c|c|c|c|c|}
\hline $\begin{array}{l}\text { Author, Date } \\
\& \text { Country }\end{array}$ & Aims and Objectives & Sample and Settings & $\begin{array}{l}\text { Methodology and } \\
\text { Measures }\end{array}$ & Results & Strengths & Limitations \\
\hline $\begin{array}{l}\text { Bell et al. } \\
\text { (2019). } \\
\text { UK }\end{array}$ & $\begin{array}{l}\text { To examine direct } \\
\text { exposure to traumatic } \\
\text { events at work. To } \\
\text { assess levels of } \\
\text { compassion fatigue } \\
\text { and their relationship } \\
\text { to risk and protective } \\
\text { factors. }\end{array}$ & $\begin{array}{l}\mathrm{N}=36 ; 21 \text { males and } \\
15 \text { females. } \\
\text { Twenty-one nurses } \\
\text { (response rate } 80 \% \text { ) } \\
\text { and } 24 \text { correctional } \\
\text { officers (response rate } \\
64 \% \text { ). Overall } \\
\text { response rate, } 72 \% \text {. } \\
\text { Inpatient healthcare } \\
\text { centre, care and } \\
\text { separation unit and } \\
\text { mental health in-reach } \\
\text { team of one prison. }\end{array}$ & $\begin{array}{l}\text { Quantitative -bivariate } \\
\text { and regression } \\
\text { analysis. } \\
\text { Unvalidated self- } \\
\text { report questionnaire } \\
\text { about exposure to } \\
\text { traumatic events, } \\
\text { organisational support, } \\
\text { professional } \\
\text { background and } \\
\text { demographics. } \\
\text { The Professional } \\
\text { Quality of Life Scale } \\
\text { (ProQOL; Stamm, } \\
\text { 2002) }\end{array}$ & $\begin{array}{l}\text { All staff had } \\
\text { experienced at least } \\
\text { one traumatic event at } \\
\text { work, with most } \\
\text { witnessing fatal or } \\
\text { near fatal incidents. } \\
57 \% \text { of nurses and } \\
53 \% \text { of correctional } \\
\text { officers required } \\
\text { medical support } \\
\text { following a personal } \\
\text { assault. } \\
\text { Compassion fatigue } \\
\text { was reported as low } \\
\text { by } 36 \% \text { and medium } \\
\text { by } 64 \% \text { of } \\
\text { participants. } \\
\text { Lower levels of } \\
\text { compassion fatigue } \\
\text { were associated with } \\
\text { feeling skilled and } \\
\text { supported by } \\
\text { managers and } \\
\text { colleagues. }\end{array}$ & $\begin{array}{l}\text { Clear aims and } \\
\text { objectives. } \\
\text { Good } \\
\text { acknowledgement of } \\
\text { study limitations. }\end{array}$ & $\begin{array}{l}\text { Small sample size, } \\
\text { study underpowered. } \\
\text { Not all the results } \\
\text { were reported. }\end{array}$ \\
\hline
\end{tabular}




\begin{tabular}{|c|c|c|c|c|c|c|}
\hline $\begin{array}{l}\text { Author, Date } \\
\& \text { Country }\end{array}$ & Aims and Objectives & Sample and Settings & $\begin{array}{c}\text { Methodology and } \\
\text { Measures }\end{array}$ & Results & Strengths & Limitations \\
\hline $\begin{array}{l}\text { Rhineberger- } \\
\text { Dunn et al. } \\
\text { (2016). }\end{array}$ & $\begin{array}{l}\text { To explore the extent } \\
\text { to which probation/ } \\
\text { parole officers and } \\
\text { residential officers, } \\
\text { experience secondary } \\
\text { trauma. To investigate } \\
\text { if there are any } \\
\text { differences between } \\
\text { the groups in the } \\
\text { variables that predict } \\
\text { secondary trauma. }\end{array}$ & $\begin{array}{l}\mathrm{N}=277 ; 126 \text { males } \\
\text { and } 127 \text { females. } \\
\text { Probation/ parole } \\
\text { officers (response rate } \\
50.28 \% \text { ) or residential } \\
\text { officers (response rate } \\
37.12 \% \text { ). Overall } \\
\text { response rate } 45.04 \% \text {. } \\
\text { Departments of } \\
\text { community } \\
\text { correctional services } \\
\text { judicial districts in } \\
\text { Iowa. }\end{array}$ & $\begin{array}{l}\text { Quantitative -bivariate } \\
\text { and regression } \\
\text { analysis. } \\
\text { Online survey. } \\
\text { Secondary Traumatic } \\
\text { Stress Scale (Bride et } \\
\text { al., 2004). } \\
\text { Independent variables } \\
\text { included veteran } \\
\text { status, general health, } \\
\text { gender, education, } \\
\text { length of time in job, } \\
\text { job location (rural or } \\
\text { urban), job training } \\
\text { and direct contact } \\
\text { hours with offenders. }\end{array}$ & $\begin{array}{l}\text { Probation/parole } \\
\text { officers were more } \\
\text { likely to report } \\
\text { secondary trauma than } \\
\text { residential officers. } \\
\text { Those with better } \\
\text { health, better job } \\
\text { training, and fewer } \\
\text { contact hours with } \\
\text { offenders were less } \\
\text { likely to report } \\
\text { secondary trauma. }\end{array}$ & $\begin{array}{l}\text { Clearly defined target } \\
\text { population and } \\
\text { appropriate selection } \\
\text { procedure. } \\
\text { Included appropriate } \\
\text { variables based upon a } \\
\text { thorough literature } \\
\text { search. }\end{array}$ & $\begin{array}{l}\text { Used military veteran } \\
\text { status to draw } \\
\text { conclusions about } \\
\text { trauma. Inclusion of a } \\
\text { trauma history } \\
\text { measure would have } \\
\text { been more } \\
\text { appropriate. } \\
\text { Exact P values and } \\
\text { confidence intervals } \\
\text { were not reported. } \\
\text { Cronbach's alpha } \\
\text { levels were not } \\
\text { reported which could } \\
\text { have demonstrated } \\
\text { internal consistency of } \\
\text { the results. }\end{array}$ \\
\hline $\begin{array}{l}\text { Hatcher \& } \\
\text { Noakes } \\
(2010) .\end{array}$ & $\begin{array}{l}\text { To evaluate levels of } \\
\text { compassion fatigue } \\
\text { and vicarious trauma } \\
\text { within the sample. To } \\
\text { explore potential } \\
\text { associations between } \\
\text { vicarious trauma and } \\
\text { demographic/ }\end{array}$ & $\begin{array}{l}\text { Social workers, } \\
\text { therapists, } \\
\text { psychologists and } \\
\text { other staff providing } \\
\text { treatment to convicted } \\
\text { sex offenders across }\end{array}$ & $\begin{array}{l}\text { Mixed methods - } \\
\text { content analysis } \\
\text { (qualitative) and } \\
\text { regression analysis } \\
\text { (quantitative). }\end{array}$ & $\begin{array}{l}\text { The quantitative } \\
\text { analysis determined } \\
\text { low levels of vicarious } \\
\text { trauma. } \\
\text { Role problems was the } \\
\text { only significant } \\
\text { predictor of secondary } \\
\text { trauma. }\end{array}$ & $\begin{array}{l}\text { Nationwide sample of } \\
\text { eligible participants. } \\
\text { Controlled for a } \\
\text { variety of potentially } \\
\text { confounding variables } \\
\text { in the analysis. }\end{array}$ & $\begin{array}{l}\text { No power analysis and } \\
\text { the modest sample } \\
\text { size raises concerns } \\
\text { about power. This is } \\
\text { recognised within the } \\
\text { limitations section and } \\
\text { effect sizes have been } \\
\text { included. }\end{array}$ \\
\hline
\end{tabular}




\begin{tabular}{|c|c|c|c|c|c|c|}
\hline $\begin{array}{l}\text { Author, Date } \\
\text { \& Country }\end{array}$ & Aims and Objectives & Sample and Settings & $\begin{array}{l}\text { Methodology and } \\
\text { Measures }\end{array}$ & Results & Strengths & Limitations \\
\hline & $\begin{array}{l}\text { organizational } \\
\text { variables. } \\
\text { To qualitatively } \\
\text { explore the impact of } \\
\text { the work, support and } \\
\text { coping strategies. }\end{array}$ & $\begin{array}{l}\text { correctional settings } \\
\text { (prison and } \\
\text { community). } \\
\text { Response rate = } \\
43.69 \% \text {. }\end{array}$ & $\begin{array}{l}\text { (ProQOL; Figley, } \\
\text { 1995). } \\
\text { Impact of Events } \\
\text { scale-Revised (IES-R; } \\
\text { Weiss \& Marmar, } \\
\text { 1997). } \\
\text { The Quality of Work } \\
\text { Life Survey } \\
\text { (Armstrong \& Griffin, } \\
\text { 2004). } \\
\text { Three qualitative } \\
\text { questions on impact of } \\
\text { work, coping } \\
\text { strategies and } \\
\text { colleague support. }\end{array}$ & $\begin{array}{l}\text { Qualitative analysis } \\
\text { was grouped into } \\
\text { 'changes to } \\
\text { perceptions of } \\
\text { humanity' and } \\
\text { 'changes directly } \\
\text { affecting the self'. } \\
\text { Examples of key } \\
\text { categories included: } \\
\text { safety, professional } \\
\text { confidence and } \\
\text { suspicion. }\end{array}$ & $\begin{array}{l}\text { The qualitative } \\
\text { analysis is } \\
\text { summarised clearly in } \\
\text { a diagram. }\end{array}$ & $\begin{array}{l}\text { No information } \\
\text { regarding ethical } \\
\text { procedures reported. }\end{array}$ \\
\hline $\begin{array}{l}\text { Severson \& } \\
\text { Pettus-Davis } \\
\text { (2013). }\end{array}$ & $\begin{array}{l}\text { To explore } \\
\text { experiences of } \\
\text { secondary trauma and } \\
\text { personal and } \\
\text { organisational } \\
\text { approaches to coping. }\end{array}$ & $\begin{array}{l}\mathrm{N}=49 \\
\begin{array}{l}\text { No reported } \\
\text { demographics. }\end{array} \\
\text { Parole officers and } \\
\text { supervisors with sex } \\
\text { offenders on their } \\
\text { caseloads. }\end{array}$ & $\begin{array}{l}\text { Qualitative-- } \\
\text { type of method not } \\
\text { specified. Used } \\
\text { predefined themes } \\
\text { based around } \\
\text { symptoms of } \\
\text { secondary trauma. } \\
\\
\text { Seven focus groups } \\
\text { with 4-14 participants } \\
\text { ( } 8 \text { on average). Five } \\
\text { groups of parole }\end{array}$ & $\begin{array}{l}\text { Identified themes } \\
\text { included impact on } \\
\text { supervision (of } \\
\text { clients), impact on } \\
\text { officers' personal lives } \\
\text { and coping strategies. } \\
\text { Officers reported } \\
\text { difficulties indicative } \\
\text { of secondary trauma, } \\
\text { for example, } \\
\text { hypervigilance, } \\
\text { intimacy issues, and }\end{array}$ & $\begin{array}{l}\text { Good representation } \\
\text { of parole officers in } \\
\text { the area. } \\
\text { Four researchers } \\
\text { independently } \\
\text { analysed the data } \\
\text { before comparing and } \\
\text { finalising the results. }\end{array}$ & $\begin{array}{l}\text { Subset of a larger } \\
\text { research project not } \\
\text { designed to assess } \\
\text { secondary trauma. } \\
\text { Focus group questions } \\
\text { were not linked to } \\
\text { secondary trauma. } \\
\text { Reluctance of } \\
\text { participants to talk }\end{array}$ \\
\hline
\end{tabular}




\begin{tabular}{|c|c|c|c|c|c|c|}
\hline $\begin{array}{l}\text { Author, Date } \\
\text { \& Country }\end{array}$ & Aims and Objectives & Sample and Settings & $\begin{array}{l}\text { Methodology and } \\
\text { Measures }\end{array}$ & Results & Strengths & Limitations \\
\hline & & $\begin{array}{l}\text { Based in the } \\
\text { community. }\end{array}$ & $\begin{array}{l}\text { officers, two groups of } \\
\text { supervising parole } \\
\text { officers. }\end{array}$ & $\begin{array}{l}\text { negative impact on } \\
\text { world view. }\end{array}$ & $\begin{array}{l}\text { Good sample size for } \\
\text { qualitative research. }\end{array}$ & $\begin{array}{l}\text { about sensitive topics } \\
\text { in a focus group. }\end{array}$ \\
\hline & & $\begin{array}{l}\text { Recruited } 90 \% \text { of } \\
\text { eligible participants in } \\
\text { the area. }\end{array}$ & 1-2 hour focus groups. & & $\begin{array}{l}\text { Consideration given to } \\
\text { ethics. }\end{array}$ & $\begin{array}{l}\text { No consideration of } \\
\text { influence/ orientation } \\
\text { of the researcher. }\end{array}$ \\
\hline & & & & & & $\begin{array}{l}\text { No detail of } \\
\text { recruitment strategy. }\end{array}$ \\
\hline \multirow[t]{6}{*}{$\begin{array}{l}\text { Perkins \& } \\
\text { Sprang } \\
(2013) .\end{array}$} & \multirow{6}{*}{$\begin{array}{l}\text { Aimed to examine } \\
\text { compassion fatigue } \\
\text { within a sample of } \\
\text { counsellors } \\
\text { specialising in } \\
\text { substance dependency } \\
\text { treatment. }\end{array}$} & $\begin{array}{l}\mathrm{N}=20 ; 8 \text { males and } 12 \\
\text { females. }\end{array}$ & $\begin{array}{l}\text { Qualitative with a } \\
\text { quantitative element- } \\
\text { type of qualitative }\end{array}$ & \multirow{6}{*}{$\begin{array}{l}\text { The qualitative data } \\
\text { from those who scored } \\
\text { high for compassion } \\
\text { fatigue suggested } \\
\text { counsellors with a } \\
\text { personal history of } \\
\text { addiction problems or } \\
\text { family members in } \\
\text { recovery were more } \\
\text { vulnerable and } \\
\text { working with women } \\
\text { was more challenging. }\end{array}$} & $\begin{array}{l}\text { Carefully selected } \\
\text { representative sample. }\end{array}$ & $\begin{array}{l}\text { Paid £30 incentive to } \\
\text { participants. }\end{array}$ \\
\hline & & $\begin{array}{l}\text { Substance abuse } \\
\text { counsellors working } \\
\text { with male and female } \\
\text { offenders. }\end{array}$ & $\begin{array}{l}\text { method not specified. } \\
\text { Compared qualitative } \\
\text { data to scores on the } \\
\text { ProQOL. }\end{array}$ & & $\begin{array}{l}\text { Step by step } \\
\text { description of } \\
\text { qualitative analysis. } \\
\text { Use of second coder }\end{array}$ & $\begin{array}{l}25 \% \text { of the sample } \\
\text { declined recording } \\
\text { meaning notes had to } \\
\text { be written instead. }\end{array}$ \\
\hline & & \multirow{4}{*}{$\begin{array}{l}\text { Ten working in } \\
\text { prisons and } 10 \\
\text { working in community } \\
\text { settings. }\end{array}$} & $\begin{array}{l}\text { Individual qualitative } \\
\text { interviews. }\end{array}$ & & $\begin{array}{l}\text { showed } 100 \% \\
\text { agreement on codes. }\end{array}$ & $\begin{array}{l}\text { Omitted those scoring } \\
\text { 'moderate' on the }\end{array}$ \\
\hline & & & $\begin{array}{l}\text { The Professional } \\
\text { Quality of Life Scale }\end{array}$ & & $\begin{array}{l}\text { Clarity around consent } \\
\text { procedures and ethical }\end{array}$ & ProQOL. \\
\hline & & & $\begin{array}{l}\text { (ProQOL; Stamm, } \\
\text { 2002). }\end{array}$ & & approval. & \multirow{2}{*}{$\begin{array}{l}\text { No rational for } \\
\text { including the empathy } \\
\text { measure, it was only } \\
\text { mentioned once the } \\
\text { results. }\end{array}$} \\
\hline & & & $\begin{array}{l}\text { The General Empathy } \\
\text { Scale (Caruso and } \\
\text { Mayer, 1998). }\end{array}$ & & & \\
\hline
\end{tabular}




\begin{tabular}{|c|c|c|c|c|c|c|}
\hline $\begin{array}{l}\text { Author, Date } \\
\text { \& Country }\end{array}$ & Aims and Objectives & Sample and Settings & $\begin{array}{l}\text { Methodology and } \\
\text { Measures }\end{array}$ & Results & Strengths & Limitations \\
\hline $\begin{array}{l}\text { Steed \& } \\
\text { Bicknell } \\
(2001) .\end{array}$ & $\begin{array}{l}\text { Aimed to explore the } \\
\text { occurrence of } \\
\text { secondary traumatic } \\
\text { stress and its } \\
\text { relationship to } \\
\text { exposure to traumatic } \\
\text { material and level of } \\
\text { training. }\end{array}$ & $\begin{array}{l}\mathrm{N}=67 ; 21 \text { males and } \\
46 \text { females. } \\
\text { Therapists working } \\
\text { with sexual offenders. } \\
\text { Psychologists (43), } \\
\text { social workers (13) } \\
\text { and other various } \\
\text { professions (11). }\end{array}$ & $\begin{array}{l}\text { Quantitative - } \\
\text { trend analysis. } \\
\text { Compassion } \\
\text { Satisfaction/ Fatigue } \\
\text { Self-Test for Helpers } \\
\text { (Stamm 1995, } 1996 \text { \& } \\
\text { 1997). } \\
\text { Impact of Events } \\
\text { Scale-Revised (IES-R; } \\
\text { Weiss \& Marmar, } \\
\text { 1997). } \\
\text {. }\end{array}$ & $\begin{array}{l}46.2 \% \text { of the sample } \\
\text { were categorised as } \\
\text { being at moderate or } \\
\text { higher risk of } \\
\text { compassion fatigue. } \\
\text { Low levels of } \\
\text { secondary trauma } \\
\text { were identified as } \\
\text { measured by the IES- } \\
\text { R, no clinically } \\
\text { significant scores. } \\
\text { Therapists with the } \\
\text { least and the most } \\
\text { experience engaged } \\
\text { the most in avoidance. }\end{array}$ & $\begin{array}{l}\text { The design of the } \\
\text { study and measures } \\
\text { used were largely } \\
\text { appropriate to the aims } \\
\text { of the study. }\end{array}$ & $\begin{array}{l}\text { Limited information } \\
\text { regarding recruitment. } \\
\text { They acknowledge the } \\
\text { study is 'severely } \\
\text { underpowered'. } \\
\text { Several of the results } \\
\text { were purely } \\
\text { descriptive where } \\
\text { statistical analysis } \\
\text { would have been } \\
\text { appropriate. }\end{array}$ \\
\hline $\begin{array}{l}\text { Carmel \& } \\
\text { Friedlander } \\
(2009) .\end{array}$ & $\begin{array}{l}\text { Aimed to explore if } \\
\text { levels of secondary } \\
\text { trauma and } \\
\text { compassion fatigue } \\
\text { would relate to the } \\
\text { working alliance as } \\
\text { reported by therapists. }\end{array}$ & $\begin{array}{l}N=106 ; 50 \text { males and } \\
56 \text { females. } \\
\text { Therapists working } \\
\text { with male sexual } \\
\text { offenders. } \\
\text { Based in inpatient } \\
\text { hospitals, outpatient, } \\
\text { community mental } \\
\text { health, correctional }\end{array}$ & $\begin{array}{l}\text { Quantitative - } \\
\text { regression analysis. } \\
\text { Internet survey. }\end{array}$ & $\begin{array}{l}\text { Secondary trauma } \\
\text { could not significantly } \\
\text { predict working } \\
\text { alliance outcomes. }\end{array}$ & $\begin{array}{l}\text { Well-designed study } \\
\text { with sufficient detail } \\
\text { provided to enable } \\
\text { replication. } \\
\text { Included theoretical } \\
\text { orientation. } \\
\text { Good consideration of } \\
\text { limitations in terms of } \\
\text { inability to generalise }\end{array}$ & $\begin{array}{l}\text { Low response rate. } \\
\text { Participants completed } \\
\text { the alliance measure in } \\
\text { reference to "the last } \\
\text { offender client" they } \\
\text { saw. This may not } \\
\text { have been } \\
\text { representative of } \\
\text { overall working } \\
\text { alliances. }\end{array}$ \\
\hline
\end{tabular}




\begin{tabular}{|c|c|c|c|c|c|c|}
\hline $\begin{array}{l}\text { Author, Date } \\
\text { \& Country }\end{array}$ & Aims and Objectives & Sample and Settings & $\begin{array}{l}\text { Methodology and } \\
\text { Measures }\end{array}$ & Results & Strengths & Limitations \\
\hline & & $\begin{array}{l}\text { facilities, independent } \\
\text { practice and others. } \\
\text { Response rate= } \\
16.8 \% \text {. }\end{array}$ & $\begin{array}{l}\text { Professional Quality } \\
\text { of Life Scale-- } \\
\text { Revised (ProQOL; } \\
\text { Stamm, 2005). } \\
\text { Impact of Event } \\
\text { Scale-Revised (IES- } \\
\text { R; Weiss \& Marmar, } \\
\text { 1997). }\end{array}$ & & $\begin{array}{l}\text { findings to less } \\
\text { experienced therapists. }\end{array}$ & $\begin{array}{l}\text { Unknown if the study } \\
\text { was appropriately } \\
\text { powered. }\end{array}$ \\
\hline $\begin{array}{l}\text { Kadambi \& } \\
\text { Truscott } \\
\text { (2003). } \\
\text { Canada }\end{array}$ & $\begin{array}{l}\text { Aimed to establish the } \\
\text { presence of vicarious } \\
\text { trauma in addition to } \\
\text { identifying any } \\
\text { mitigating variables. }\end{array}$ & $\begin{array}{l}\mathrm{N}=91 ; 42 \text { males and } \\
49 \text { females. } \\
\text { Therapists } \\
\text { providing sex offender } \\
\text { treatment. } \\
\text { Response rate }=43 \% \text {. }\end{array}$ & $\begin{array}{l}\text { Mailed surveys. } \\
\text { Treatment provider } \\
\text { survey (self- } \\
\text { developed). } \\
\text { Traumatic Stress } \\
\text { Institute Belief Scale - } \\
\text { Revision L (Pearlman, } \\
\text { 1996). } \\
\text { The Impact of Event } \\
\text { Scale (IES; Horowitz, } \\
\text { Wilner \& Alvarez, } \\
\text { 1980). }\end{array}$ & $\begin{array}{l}\text { Moderate to severe } \\
\text { levels of secondary } \\
\text { trauma reported by } \\
24 \% \text { of the sample. } \\
\text { Levels of vicarious } \\
\text { trauma did not } \\
\text { significantly differ to a } \\
\text { criterion reference } \\
\text { group of mental health } \\
\text { professionals. } \\
\text { The only mitigating } \\
\text { variable identified was } \\
\text { having a venue to } \\
\text { discuss the personal } \\
\text { impact of work. }\end{array}$ & $\begin{array}{l}\text { Found the sample } \\
\text { demographics to be } \\
\text { representative of sex } \\
\text { offender therapists in } \\
\text { Canada. } \\
\text { Attempted to limit } \\
\text { sample only to people } \\
\text { working primarily } \\
\text { with sex offenders. }\end{array}$ & $\begin{array}{l}\text { No description of who } \\
\text { was invited to } \\
\text { participate (settings/ } \\
\text { population worked } \\
\text { with) or how their } \\
\text { addresses were } \\
\text { obtained. } \\
\text { No information } \\
\text { regarding ethical } \\
\text { procedures reported. }\end{array}$ \\
\hline
\end{tabular}




\begin{tabular}{|c|c|c|c|c|c|c|}
\hline $\begin{array}{l}\text { Author, Date } \\
\text { \& Country }\end{array}$ & Aims and Objectives & Sample and Settings & $\begin{array}{l}\text { Methodology and } \\
\text { Measures }\end{array}$ & Results & Strengths & Limitations \\
\hline & & & $\begin{array}{l}\text { The Maslach Burnout } \\
\text { Inventory (Maslach, } \\
\text { Jackson \& Leiter, } \\
\text { 1996). }\end{array}$ & & & \\
\hline $\begin{array}{l}\text { Merhav et al. } \\
\text { (2018). } \\
\text { Israel }\end{array}$ & $\begin{array}{l}\text { To explore whether } \\
\text { attachment styles were } \\
\text { correlated with } \\
\text { vicarious trauma, as } \\
\text { measured by } \\
\text { disruption in cognitive } \\
\text { schemas of trust and } \\
\text { safety. }\end{array}$ & $\begin{array}{l}\mathrm{N}=189 ; 41 \text { males and } \\
145 \text { females. } \\
\text { Probation officers who } \\
\text { are social workers. } \\
\text { Clients of probation } \\
\text { services. } \\
\text { Response rate= } \\
73.3 \% \text {. }\end{array}$ & $\begin{array}{l}\text { Quantitative - } \\
\text { ANOVA and } \\
\text { regression analysis. } \\
\text { Trauma and } \\
\text { Attachment Belief } \\
\text { Scale (TABS; } \\
\text { Pearlman, 2003). } \\
\text { Experience in Close } \\
\text { Relationships Scale } \\
\text { (ECR; Brennan, Clark } \\
\text { \& Shaver, 1998). } \\
\text { Trauma History } \\
\text { Screen (THS; Carlson } \\
\text { et al., 2011). }\end{array}$ & $\begin{array}{l}\text { Those with secure } \\
\text { attachment styles } \\
\text { reported lower levels } \\
\text { of vicarious trauma } \\
\text { than those with } \\
\text { insecure attachment } \\
\text { styles. } \\
\text { The relationship } \\
\text { between history of } \\
\text { personal trauma and } \\
\text { disruption in the safety } \\
\text { schema (not the trust } \\
\text { schema) was } \\
\text { moderated by } \\
\text { attachment style. }\end{array}$ & $\begin{array}{l}\text { Well designed, high } \\
\text { quality study. } \\
\text { Questionnaire } \\
\text { distributed to all } \\
\text { probation officers in } \\
\text { the country. }\end{array}$ & $\begin{array}{l}\text { Only utilised the trust } \\
\text { and safety subscales } \\
\text { from the TABS } \\
\text { (relating to self and } \\
\text { others) to measure } \\
\text { vicarious trauma. The } \\
\text { scale had not been } \\
\text { designed or validated } \\
\text { to be used in this way. } \\
\text { The subscales } \\
\text { produced low } \\
\text { reliability, so the self } \\
\text { and others aspect were } \\
\text { combined. }\end{array}$ \\
\hline $\begin{array}{l}\text { Morran } \\
(2008) \text {. }\end{array}$ & $\begin{array}{l}\text { No clear aims/ } \\
\text { objectives. }\end{array}$ & $\begin{array}{l}\mathrm{N}=30 ; 10 \text { males and } \\
20 \text { females. } \\
\text { Practitioners working } \\
\text { within domestic } \\
\text { violence offender } \\
\text { programs. } 16 \\
\text { probation officers and }\end{array}$ & $\begin{array}{l}\text { Qualitative - } \\
\text { type of qualitative } \\
\text { method not specified. } \\
\text { Unstandardised } \\
\text { questionnaire. }\end{array}$ & $\begin{array}{l}\text { Work found to impact } \\
\text { on the self, views on } \\
\text { relationships and to } \\
\text { elicit complex } \\
\text { emotions. } \\
\text { More females } \\
\text { indicated to }\end{array}$ & $\begin{array}{l}\text { Rich data about the } \\
\text { impact of working } \\
\text { with male perpetrators } \\
\text { of domestic violence. } \\
\text { Novel research. }\end{array}$ & $\begin{array}{l}\text { Secondary trauma was } \\
\text { not a clearly defined } \\
\text { concept within this } \\
\text { study. } \\
\text { No rational for } \\
\text { analysis or any }\end{array}$ \\
\hline
\end{tabular}




\begin{tabular}{|c|c|c|c|c|c|c|}
\hline $\begin{array}{l}\text { Author, Date } \\
\text { \& Country }\end{array}$ & Aims and Objectives & Sample and Settings & $\begin{array}{l}\text { Methodology and } \\
\text { Measures }\end{array}$ & Results & Strengths & Limitations \\
\hline & & $\begin{array}{l}14 \text { other practitioners } \\
\text { (psychotherapy, social } \\
\text { work, and women's } \\
\text { support work). }\end{array}$ & $\begin{array}{l}\text { Findings from initial } \\
\text { phase of ongoing } \\
\text { research. }\end{array}$ & $\begin{array}{l}\text { experience secondary } \\
\text { trauma. } \\
\text { Training required } \\
\text { updating. Support } \\
\text { offered from } \\
\text { management and } \\
\text { colleagues was } \\
\text { insufficient. }\end{array}$ & $\begin{array}{l}\text { Reported results were } \\
\text { supported by the data. }\end{array}$ & $\begin{array}{l}\text { description of the } \\
\text { analytic approach. } \\
\text { No reported } \\
\text { consideration given to } \\
\text { ethics or the influence } \\
\text { of the researcher on } \\
\text { the findings. }\end{array}$ \\
\hline $\begin{array}{l}\text { Munger, } \\
\text { Savage \& } \\
\text { Panosky } \\
(2015) .\end{array}$ & $\begin{array}{l}\text { Aimed to determine if } \\
\text { vicarious } \\
\text { traumatisation exists } \\
\text { within the sample. }\end{array}$ & $\begin{array}{l}\mathrm{N}=205 ; 19 \text { males and } \\
167 \text { females. } \\
\text { Correctional health } \\
\text { nurses practicing in } \\
\text { secured settings. } \\
\text { Response rate }= \\
10.1 \%\end{array}$ & $\begin{array}{l}\text { Quantitative - } \\
\text { descriptive statistics } \\
\text { and t-tests. } \\
\text { Mailed paper survey. } \\
\text { The Professional } \\
\text { Quality of Life Scale } \\
\text { (reference not } \\
\text { provided). }\end{array}$ & $\begin{array}{l}\text { Vicarious } \\
\text { traumatisation found } \\
\text { to exist among } \\
\text { correctional health } \\
\text { nurses. } \\
\text { Sample at moderate to } \\
\text { low risk of secondary } \\
\text { trauma, with over half } \\
\text { scoring at moderate } \\
\text { risk. } \\
\text { Of the } 67 \% \text { of } \\
\text { participants exposed } \\
\text { to workplace violence, } \\
\text { lower compassion } \\
\text { satisfaction and higher } \\
\text { secondary trauma } \\
\text { were reported. }\end{array}$ & $\begin{array}{l}\text { Random sample. } \\
\text { Measured experience } \\
\text { of violence and } \\
\text { included this variable } \\
\text { in the analysis. } \\
\text { Reported ethical } \\
\text { approval and consent } \\
\text { procedures. }\end{array}$ & $\begin{array}{l}\text { Used the ProQOL as a } \\
\text { proxy measure for } \\
\text { vicarious trauma. } \\
\text { Referred to secondary } \\
\text { traumatic stress } \\
\text { throughout. } \\
\text { Purchased mailing list } \\
\text { from an independent } \\
\text { marketing group. }\end{array}$ \\
\hline
\end{tabular}


Table 2:

Quality scores for the included qualitative studies

\begin{tabular}{lllll}
\hline $\begin{array}{l}\text { CASP questions (Critical Appraisal Skills } \\
\text { Programme, 2018). }\end{array}$ & Severson, 2013 & Morran, 2008 & Hatcher, 2010 & Perkins, 2013 \\
\hline Q1. Clear aims? & 2 & 0 & 2 & 2 \\
Q2. Qualitative methodology appropriate? & 2 & 0 & 1 & 2 \\
Q3. Research design appropriate? & 1 & 0 & 2 & 2 \\
Q4. Recruitment strategy appropriate? & 2 & 2 & 2 & 2 \\
Q5. Data collection appropriate? & 1 & 1 & 0 & 0 \\
$\begin{array}{l}\text { Q6. Relationship between researcher and } \\
\text { participants considered? }\end{array}$ & 0 & 0 & 1 & 2 \\
Q7. Ethical issues considered? & 2 & 0 & 1 & 2 \\
Q8. Data analysis rigorous? & 1 & 1 & 2 & 2 \\
Q9. Clear statement of findings? & 1 & 2 & 1 & 2
\end{tabular}

*Articles were awarded 2 points if a criterion was fully met, 1 point if a criterion was partially met or 0 points if a criterion was not met or 'can't tell'. 
Table 3:

Quality scores for the included quantitative studies

\begin{tabular}{|c|c|c|c|c|c|c|c|c|}
\hline $\begin{array}{l}\text { AXIS Questions (Downes } \\
\text { et al., 2016). }\end{array}$ & $\begin{array}{l}\text { Rhineberger- } \\
\text { Dunn, } 2016\end{array}$ & Steed, 2001 & Carmel, 2009 & Kadambi, 2003 & $\begin{array}{l}\text { Merhav, } \\
2018\end{array}$ & $\begin{array}{l}\text { Munger, } \\
2015\end{array}$ & Bell, 2019 & $\begin{array}{l}\text { Hatcher, } \\
2010\end{array}$ \\
\hline 1. Clear aims? & 2 & 2 & 2 & 2 & 2 & 1 & 2 & 2 \\
\hline $\begin{array}{l}\text { 2. Study design } \\
\text { appropriate for aims? }\end{array}$ & 2 & 2 & 2 & 2 & 2 & 1 & 2 & 2 \\
\hline 3. Sample size justified? & 0 & 0 & 0 & 0 & 2 & 0 & 0 & 0 \\
\hline $\begin{array}{l}\text { 4. Target population } \\
\text { clearly defined? }\end{array}$ & 2 & 1 & 2 & 2 & 2 & 2 & 1 & 2 \\
\hline $\begin{array}{l}\text { 5. Sample representative } \\
\text { of the target population? }\end{array}$ & 2 & 0 & 2 & 2 & 2 & 1 & 1 & 2 \\
\hline $\begin{array}{l}\text { 6. Adequate selection } \\
\text { process? }\end{array}$ & 2 & 0 & 2 & 2 & 2 & 1 & 2 & 2 \\
\hline $\begin{array}{l}\text { 7. Measures taken to } \\
\text { address non-responders? }\end{array}$ & 0 & 0 & 0 & 0 & 0 & 0 & 0 & 0 \\
\hline $\begin{array}{l}\text { 8. Variables measured } \\
\text { appropriate to study aims? }\end{array}$ & 2 & 2 & 2 & 1 & 1 & 1 & 2 & 1 \\
\hline $\begin{array}{l}\text { 9. Variables measured } \\
\text { correctly? }\end{array}$ & 1 & 2 & 2 & 1 & 1 & 2 & 1 & 2 \\
\hline $\begin{array}{l}\text { 10. Clear how statistical } \\
\text { significance is } \\
\text { determined? }\end{array}$ & 1 & 2 & 2 & 1 & 2 & 2 & 2 & 2 \\
\hline
\end{tabular}




\begin{tabular}{|c|c|c|c|c|c|c|c|c|}
\hline $\begin{array}{l}\text { AXIS Questions (Downes } \\
\text { et al., 2016). }\end{array}$ & $\begin{array}{l}\text { Rhineberger- } \\
\text { Dunn, } 2016\end{array}$ & Steed, 2001 & Carmel, 2009 & Kadambi, 2003 & $\begin{array}{l}\text { Merhav, } \\
2018\end{array}$ & $\begin{array}{l}\text { Munger, } \\
2015\end{array}$ & Bell, 2019 & $\begin{array}{l}\text { Hatcher, } \\
2010\end{array}$ \\
\hline $\begin{array}{l}11 . \text { Methods sufficiently } \\
\text { described to allow } \\
\text { replication? }\end{array}$ & 2 & 1 & 2 & 1 & 2 & 2 & 2 & 2 \\
\hline $\begin{array}{l}\text { 12. Adequate descriptive } \\
\text { data of the sample } \\
\text { presented? }\end{array}$ & 2 & 2 & 2 & 2 & 2 & 2 & 2 & 2 \\
\hline $\begin{array}{l}\text { 13. Response rate raises } \\
\text { concerns about non- } \\
\text { response bias? }{ }^{*}\end{array}$ & 1 & 1 & 0 & 1 & 2 & 0 & 2 & 1 \\
\hline $\begin{array}{l}\text { 14. Was information } \\
\text { about non-responders } \\
\text { described (if appropriate?) }\end{array}$ & 1 & 0 & 0 & 1 & N/A & 0 & N/A & 0 \\
\hline $\begin{array}{l}15 . \text { Results internally } \\
\text { consistent? }\end{array}$ & 0 & 2 & 2 & 1 & 1 & 0 & 2 & 1 \\
\hline $\begin{array}{l}\text { 16. All results for planned } \\
\text { analyses presented? }\end{array}$ & 2 & 2 & 2 & 2 & 2 & 1 & 1 & 2 \\
\hline $\begin{array}{l}\text { 17. Conclusions justified } \\
\text { by results? }\end{array}$ & 2 & 1 & 2 & 2 & 2 & 2 & 2 & 2 \\
\hline $\begin{array}{l}\text { 18. Study limitations } \\
\text { discussed? }\end{array}$ & 2 & 1 & 2 & 2 & 2 & 2 & 2 & 2 \\
\hline $\begin{array}{l}\text { 19. Conflicts of interest/ } \\
\text { funding? }\end{array}$ & 1 & 0 & 0 & 0 & 0 & 2 & 1 & 0 \\
\hline
\end{tabular}




\begin{tabular}{lllllccc}
\hline $\begin{array}{c}\text { AXIS Questions (Downes } \\
\text { et al., 2016). }\end{array}$ & $\begin{array}{c}\text { Rhineberger- } \\
\text { Dunn, 2016 }\end{array}$ & Steed, 2001 & Carmel, 2009 & Kadambi, 2003 & $\begin{array}{c}\text { Merhav, } \\
\text { 2018 }\end{array}$ & $\begin{array}{c}\text { Munger, } \\
2015\end{array}$ & $\begin{array}{c}\text { Bell, 2019 } \\
\text { Hatcher, } \\
2010\end{array}$ \\
\hline $\begin{array}{l}\text { 20. Ethical approval/ } \\
\text { consent attained? }\end{array}$ & 1 & 0 & 1 & 0 & 2 & 2 & 0 \\
\hline
\end{tabular}

*Articles were awarded 2 points if a criterion was fully met, 1 point if a criterion was partially met or 0 points if a criterion was not met or 'can't tell'. If a question was not applicable to a research study, N/A is indicated.

Q13 scored negatively

Q13 response rates: $50 \%+$ score $2,30-49 \%$ score $1,29 \%$ and below score 0. 
Figure 1: Flow chart demonstrating literature review search strategy

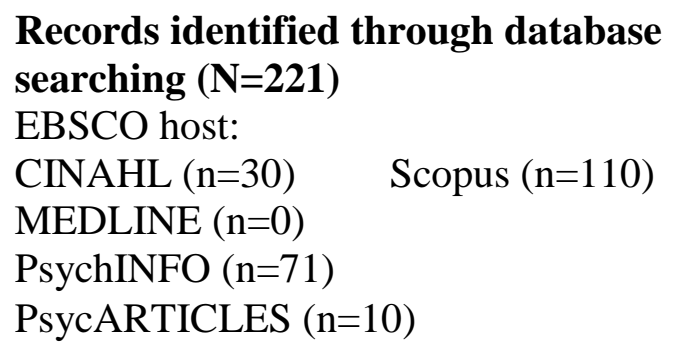

Records identified through database searching $(\mathrm{N}=\mathbf{2 2 1})$

EBSCO host:

CINAHL $(n=30) \quad$ Scopus $(n=110)$

$\operatorname{MEDLINE}(\mathrm{n}=0)$

PsychINFO $(\mathrm{n}=71)$

PsycARTICLES $(\mathrm{n}=10)$

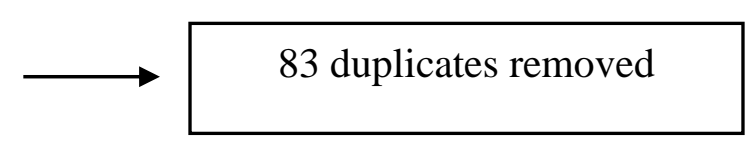

107 articles excluded due to a clear lack of relevance to the review topic

21 full text articles excluded, with reasons:

Mixed sample of clinicians working with survivors and offenders $(n=9)$

Include staff not in direct contact with offenders $(n=4)$ Not focussed on VT or STS $(n=6)$

Juvenile offender population $(n=1)$

Descriptive review $(n=1)$

Articles meeting inclusion criteria $(n=11)$ 